\title{
Behavioural patterns of the soft-shell clam Mya arenaria: implications for benthic oxygen and nitrogen dynamics
}

\author{
Nicola Camillini ${ }^{1,2, *}$, Morten Larsen ${ }^{1}$, Ronnie N. Glud ${ }^{1,3}$ \\ ${ }^{1}$ Department of Biology, University of Southern Denmark, Campusvej 55, 5230 Odense M, Denmark \\ ${ }^{2}$ Centre for Coastal Biogeochemistry, Southern Cross University, Military Road (PO Box 157), 2480 Lismore, \\ New South Wales, Australia \\ ${ }^{3}$ Department of Ocean and Environmental Sciences, Tokyo University of Marine Science and Technology, 4-5-7 Konan, \\ Minato-ku, Tokyo, 108-8477, Japan
}

\begin{abstract}
It is well established that benthic infauna alter sediment biogeochemistry, but the importance of their behavioural patterns in biogeochemical processes has only recently been fully appreciated. Using arrays of $\mathrm{O}_{2}$ microoptodes, siphon imaging, accelerometer loggers and different incubation approaches, we investigated the importance of behavioural patterns of the soft-shell clam Mya arenaria for benthic $\mathrm{O}_{2}$ and nitrogen dynamics. The investigations resolved a new behavioural component of buried M. arenaria: pedal water ejection (PWE). During PWE, the clams contracted their valves while briefly closing the siphon to expel oxic water previously accumulated within the mantle cavity through the pedal gape. Consequently, an upward-moving oxic plume embedded most of the shell, and oxia at the shell-sediment interface was observed for $15 \%$ of the total time of investigation. The buried clams displayed 2 additional behavioural stages: resting (R) and ventilation (V) that occurred for 57 and $28 \%$ of the time, respectively. During the V and PWE stages, the siphon of the clam was elongated above the sediment surface and surrounded by a dynamic oxic halo; both behavioural stages thus markedly increase the sediment oxygenation. The resolved irrigation patterns enhanced the benthic exchange of $\mathrm{O}_{2}$ and $\mathrm{NH}_{4}{ }^{+}$as well as the benthic denitrification rate, presumably via increased benthic $\mathrm{NO}_{3}{ }^{-}$supply and production. Particularly, the extensive sediment irrigation induced by the PWE stage has important implications for benthic nutrient cycling as well as for sediment oxidation and biogeochemical function of coastal sediments.
\end{abstract}

KEY WORDS: Fauna behaviour · Bioirrigation $\cdot$ Mya arenaria $\cdot$ Oxygen $\cdot$ Nitrogen $\cdot$ Denitrification · Biogeochemistry

\section{INTRODUCTION}

Infauna ventilate their burrow structures to sustain their respiration and feeding (Boudreau \& Marinelli 1994, Kristensen et al. 2012). This activity alters the physical and chemical properties of surface sediments and transforms the 1-dimensional, vertically layered distribution of biogeochemical processes into a 3-dimensional system (Kristensen 2000, Aller

\footnotetext{
*Corresponding author: nicola@biology.sdu.dk
}

2014). Bioirrigation supplies microbial communities with organic substrates and oxidants while removing their metabolites; thus, bioirrigation enhances benthic nutrient fluxes and the mineralization rate of organic matter (Aller 1982, Aller \& Yingst 1998, Glud et al. 2003). Infaunal species feature different ventilation mechanisms, but typically their ventilation alternates with resting stages (e.g. Forster \& Graf 1995, Jovanovic et al. 2014) and induces intermittent

(C) The authors 2019. Open Access under Creative Commons by Attribution Licence. Use, distribution and reproduction are unrestricted. Authors and original publication must be credited. 
oxic-anoxic fluctuations in the sediment (Wenzhöfer \& Glud 2004, Volkenborn et al. 2012). This alternation increases the internal nutrient dynamics and sustains coupled metabolic pathways such as ammonification, nitrification and denitrification (Aller 1994, Gilbert et al. 2016). The frequency and duration of the oxic-anoxic fluctuations can select for specific microbial populations (Aller 1994), and burrow structures often host unique microbial communities featuring versatile metabolic capabilities (Kristensen \& Kostka 2005, Bertics \& Ziebis 2009, Engel et al. 2012). For example, bioirrigation typically promotes the growth of facultative aerobes like denitrifiers while impeding the development of strictly anaerobic communities (Kristensen \& Blackburn 1987, Heilskov \& Holmer 2001, Bertics \& Ziebis 2010). This is important as denitrification removes bioavailable nitrogen and can thus regulate primary production in nutrientlimited systems and alleviate eutrophication (Seitzinger et al. 2006).

The soft-shell clam Mya arenaria L. lives permanently buried in the sediment and is abundant in many temperate coastal areas, including the Baltic Sea (Brey 1991, Strasser 1998), where adult populations reach densities of 100 to 450 ind. $\mathrm{m}^{-2}$ (Kube 1996, Forster \& Zettler 2004). M. arenaria filters organic particles by extending the fused inhalant and exhalant siphons a few millimetres above the sediment surface (Henriksen et al. 1983). The burying depth of $M$. arenaria thus depends on the siphon length, which gradually increases with age. Adult specimens having shell length $>5 \mathrm{~cm}$ are typically positioned at $20 \mathrm{~cm}$ sediment depth (Zwarts \& Wanink 1989). The ventilation activity functions as a closed system (Hansen et al. 1996), with water pumped in and out the siphon without direct contact with the surrounding sediment. Accordingly, the oxidized sediment layer around the soft-shell clam has previously been attributed to either $\mathrm{O}_{2}$ diffusion through the siphon wall or to passive water advection linked to siphon retraction (Pelegrí \& Blackburn 1995, Hansen et al. 1996). Previous investigations have also shown that disturbed soft-shell clams can burrow themselves by expelling pressurised water jets through the pedal gape to remove the underlying sediment while gripping the substrate with the foot (Checa \& Cadée 1997). However, this behaviour has been attributed to specimens burrowing on the sediment surface only and has not been reported for buried clams.

This study adds to the current knowledge about the microenvironment around $M$. arenaria by using (1) arrays of $\mathrm{O}_{2}$ microoptodes either fixed on the shell or positioned in the sediment adjacent to clams, (2) imaging of the siphon aperture area and (3) accelerometer loggers mounted on the shell to resolve complex and dynamic bioirrigation patterns. This study includes the first documentation of water ejection from the pedal gape of buried clams. The biogeochemical implications of this previously undescribed behaviour are investigated by different incubation approaches, and the importance for coastal biogeochemical function is discussed.

\section{MATERIALS AND METHODS}

\subsection{Sampling site}

Sediment cores and adult specimens of Mya arenaria were collected on 4 occasions between March and October 2016 (Table 1) in a shallow inlet at Pughavn (Funen, Denmark). The sampling area had an average water depth of $0.5 \mathrm{~m}$ and a tidal amplitude of $0.3 \mathrm{~m}$ (Vedel et al. 1994). Over the sampling period, mid-water temperature and salinity ranged between 3 and $28^{\circ} \mathrm{C}$ and between 17 and 28 , respectively. The sediment type changed from sandy gravel to sandy mud towards the centre of the inlet, where sampling occurred. The sediment permeability, porosity and organic content were quantified from 3 cores collected in April 2016 (inner diameter [i.d.] × height: $5.2 \times 20 \mathrm{~cm}$ ). The sediment permeability was determined by the constant head approach (Klute \& Dirksen 1986) and amounted to $2.5 \times 10^{-12} \pm 0.3 \times 10^{-12} \mathrm{~m}^{2}$ (mean $\pm \mathrm{SD}$, hereafter omitted). Subsequently, the sediment cores were sliced in 1-2 cm layers, and porosity profiles were derived from the measured density and the water content, as determined from the weight loss after drying at $105^{\circ} \mathrm{C}$ for $12 \mathrm{~h}$. The organic content was measured as loss on ignition after combustion of the dried sediment for $24 \mathrm{~h}$ at $520^{\circ} \mathrm{C}$. The surface sediment had a porosity of $0.60 \pm$ 0.08 that gradually declined to $0.38 \pm 0.08$ at $10 \mathrm{~cm}$ depth. Similarly, the organic content at the surface declined from $1.5 \pm 0.3 \%$ to $0.8 \pm 0.1 \%$ of dry weight at $10 \mathrm{~cm}$ depth.

\subsection{Fauna and sediment sampling}

Adult specimens of $M$. arenaria (shell length 56-75 mm) were collected using a Kajak corer and immediately transferred into a bucket filled with site seawater. The in situ burial depth (distance from sediment surface to lower shell edge) varied between 15 and $20 \mathrm{~cm}$. The animals were entirely surrounded 
by an irregular but distinct $3-5 \mathrm{~mm}$, light-coloured, oxidized sediment layer. Sediment was sampled with large (i.d. $\times$ height: $9.5 \times 30 \mathrm{~cm}$ ) and small (i.d. $\times$ height: $5.2 \times 20 \mathrm{~cm}$ ) cylindrical polymethyl metacrylate core liners. Animals and sediment cores were transported to the University of Southern Denmark (Odense) within a few hours and stored in separate aquariums each filled with aerated in situ seawater. Animals were kept in storage for at least $1 \mathrm{wk}$ at a water temperature of $15^{\circ} \mathrm{C}$ and a salinity of 17 to 28 (depending on sampling day). Experiments were conducted at storage conditions using 2 different setups: (1) core liners inserted in a mini-flume aquarium (length $\times$ width $\times$ height: $52 \times 13 \times 19 \mathrm{~cm}$ ) with a recirculating water volume of $\sim 50 \mathrm{l}$ to monitor the $\mathrm{O}_{2}$ dynamics around the clam; and (2) core liners submerged in an aquarium with a $\sim 150 \mathrm{l}$ recirculating water volume for measurement of benthic $\mathrm{O}_{2}$ and nutrient fluxes and denitrification rate. In total, 7 specimens and large sediment cores were used in the mini-flume experiments, while 8 specimens and 12 sediment cores (8 large, 4 small) were used for core incubations. Except for 1 targeted experiment confirming that the activity patterns of the soft-shell

Table 1. Sampling dates and experiment replication for each type of determination. Sediment oxygenation around the shell and siphon of Mya arenaria was investigated in (1) a mini-flume set-up and (2) submerged cores with central stirring (around shell only). The submerged cores were also used in different incubation approaches to measure total $\mathrm{O}_{2}$ uptake (TOU), benthic nutrient fluxes and denitrification rate in presence of $M$. arenaria and defaunated control cores. nd: not determined

\begin{tabular}{|c|c|c|c|}
\hline $\begin{array}{l}\text { Sampling date } \\
\text { (2016) }\end{array}$ & \multicolumn{3}{|c|}{ Comments } \\
\hline 08 March & \multicolumn{3}{|c|}{$\begin{array}{l}\text { Two clams and sediment cores for mini-flume experi- } \\
\text { ments in March and April (siphon). }\end{array}$} \\
\hline 06 April & \multicolumn{3}{|c|}{$\begin{array}{l}\text { Two clams and sediment cores for mini-flume experi- } \\
\text { ments in May and June (siphon), } 3 \text { sediment cores for } \\
\text { sediment characteristics. }\end{array}$} \\
\hline 07 July & \multicolumn{3}{|c|}{$\begin{array}{l}\text { Two clams and sediment cores for mini-flume experi- } \\
\text { ments in July and August (shell). }\end{array}$} \\
\hline 18 October & \multicolumn{3}{|c|}{$\begin{array}{l}\text { Eight clams and } 12 \text { sediment cores for sediment core } \\
\text { incubations in November and December, one clam and } \\
\text { sediment core for mini-flume experiment in February } \\
2017 \text { (shell and siphon). }\end{array}$} \\
\hline \multicolumn{2}{|c|}{ Sediment oxygenation } & Mini-flume & Submerged core \\
\hline \multirow{3}{*}{\multicolumn{2}{|c|}{$\begin{array}{l}\text { Shell survey (n) } \\
\text { Siphon surveys (n) } \\
\text { Total (n) }\end{array}$}} & 910 h (3) & 2120 h (4) \\
\hline & & 302 h (5) & nd \\
\hline & & 1096 h (7) & 2120 h (4) \\
\hline \multicolumn{2}{|c|}{ No. of incubations } & $\operatorname{Mya}(\mathrm{n}=8)$ & Control $(n=4)$ \\
\hline & 76 & 37 \\
\hline \multicolumn{2}{|l|}{ Nutrient fluxes } & 40 & 22 \\
\hline \multicolumn{2}{|c|}{ Denitrification rate } & 8 & 4 \\
\hline
\end{tabular}

clam did not respond to light (data not shown), all investigations were carried out in darkness. Twice per week, animals were fed with aliquots from a culture of Rhodomonas sp. to avoid inhibition of ventilation activity by food limitation (i.e. $<1000 \mathrm{cell} \mathrm{ml}^{-1}$; Riisgård et al. 2003). Additionally, $50 \%$ of the ambient water volume of both set-ups was replaced weekly with in situ seawater to maintain $\mathrm{NH}_{4}{ }^{+}$and $\mathrm{NO}_{3}{ }^{-}$concentrations between 4 and 9 and between 28 and $47 \mu \mathrm{mol} \mathrm{l}^{-1}$, respectively. At the end of each experiment, the soft tissue of the investigated specimens was separated from the shell by immersion in boiling water $(\sim 15 \mathrm{~s})$, and the dry weight was measured after drying at $60^{\circ} \mathrm{C}$ for $3 \mathrm{~d}$ (Zwarts 1991).

\subsection{Mini-flume experiments}

Large core liners were inserted at the bottom of a small flow-through channel, and the sediment surface was aligned with the aquarium base (Fig. 1). The mini-flume aquarium had a unidirectional horizontal flow of $\sim 1.9 \mathrm{~cm} \mathrm{~s}^{-1}$. Clams were individually placed at the sediment surface and allowed to independently bury. Then, the sediment bioirrigation patterns were determined by measuring the $\mathrm{O}_{2}$ dynamics around the clams over periods of 2 to 4 wk between March 2016 and February 2017. This insight was enabled by applying an array of $\mathrm{O}_{2}$ microoptodes directly fixed to naturally performing animals, thus overcoming the spatial limitation of planar sensors. No differences were observed in the animal behaviour as a function of time.

Time-lapse images of the siphon aperture area were recorded every $30 \mathrm{~s}$ from above using a digital camera (DCM 900) and a near-infrared lamp (Kemo) (Fig. 1a). Images were processed with the free software ImageJ (http://imagej.nih.gov). The $\mathrm{O}_{2}$ distribution in the sediment surrounding the siphon and at the shellsediment interface was monitored with arrays of flexible optical fibers connected to a Firesting $\mathrm{O}_{2}$ meter (FSO2-4; PyroScience). After calibration $(0 \%$ and $100 \%$ air saturation), $1 \mathrm{O}_{2}$ microoptode (OXB230, Pyroscience) was glued on the left valve in proximity of the pedal gape (' $\mathrm{P}$ ' in 


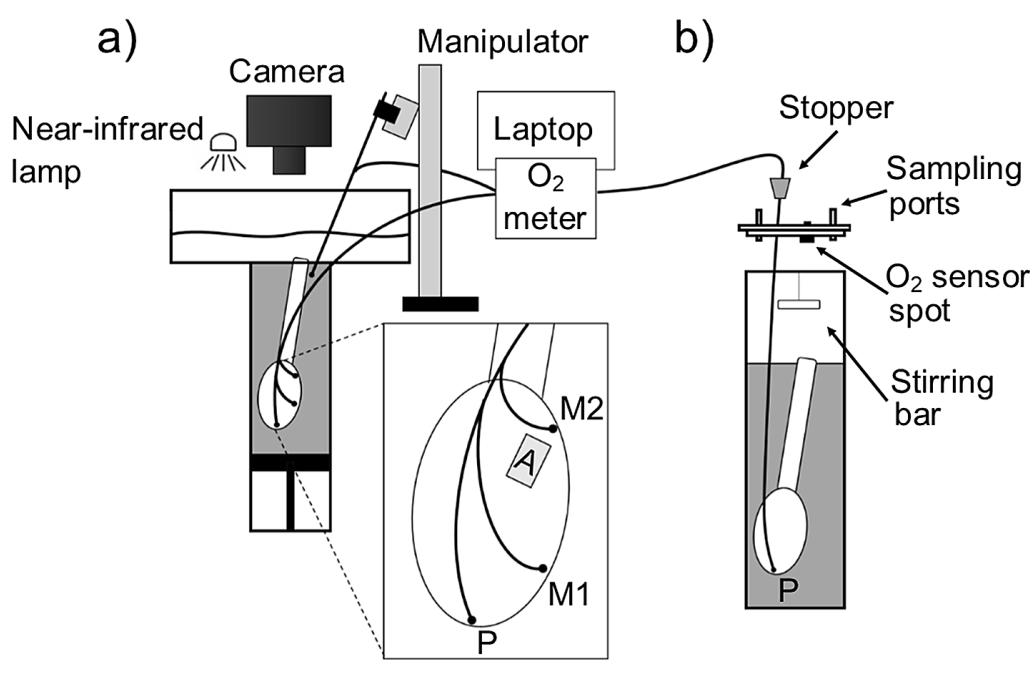

Fig. 1. (a) Schematic of the mini-flume experimental set-up to study the $\mathrm{O}_{2}$ dynamics around Mya arenaria. The sediment surface of core liners was aligned with the aquarium base prior to the addition of clams. The insert shows a magnification of the recording positions of $\mathrm{O}_{2}$ microoptodes (' $\mathrm{P}$ ', 'M1', 'M2') and accelerometer (A) fixed on the shell. (b) Incubation set-up for the benthic $\mathrm{O}_{2}$ and nutrient fluxes and denitrification rate determination. The lids used during the incubation were equipped with 2 sampling ports and contactless $\mathrm{O}_{2}$ spot fixed on the inside. In 4 cores, the clams each had a microoptode fixed at position ' $\mathrm{P}$ ' on the shell, which passed through an opening in the lid that was sealed with a stopper during the incubations

\title{
2.4. Core incubation
}

\author{
2.4.1. Initial defaunation of \\ sediment cores
}

The benthic $\mathrm{O}_{2}$ and nutrient fluxes, as well as denitrification activities, were quantified by different incubation approaches in sediment cores with and without clams. All these cores (8 large and 4 small) were collected in October 2016 and stored uncapped and submerged in the $\sim 150 \mathrm{l}$ aquarium. The day after collection, triplicate $\mathrm{O}_{2}$ sediment profiles were measured as described previously in 3 randomly selected cores equipped with stirring bars (60 RPM). The $\mathrm{O}_{2}$ penetration depth (OPD) in these undisturbed sediment cores amounted to $2.6 \pm 0.3 \mathrm{~mm}$. Subsequently, all 12 cores were sealed to induce anoxia and force macrofauna out of the sediment (Andersen \& Kristensen 1988). After $1 \mathrm{wk}$, dead or

Fig. 1a) using UV-curing adhesive glue (Dymax 426). Two clams had each 2 additional microoptodes fixed at increasing distance from the pedal gape on the ventral margin ('M1' and 'M2' in Fig. 1a) and a triaxial acceleration data logger (AXY-3 TechnoSmArt) mounted on the shell ('A' in Fig. 1a). The AXY-3 data logger recorded the acceleration on 3 axes (range: $\pm 19.62 \mathrm{~m} \mathrm{~s}^{-2}$ ) at $1 \mathrm{~Hz}$ and 8 -bit resolution and thus resolved the behavioural dynamics and body postures of buried individuals. Accelerometers were heatsealed in polyethylene tubes and attached to the left valve using a small piece of Velcro ${ }^{\circledR}\left(<1.5 \mathrm{~cm}^{2}\right)$ to determine the soft-shell clam body orientation in space and movements (Coquereau et al. 2016).

The $\mathrm{O}_{2}$ distribution around the siphon was investigated with microoptodes inserted in a glass Pasteur pipette (tip i.d. $1 \mathrm{~mm}_{\text {i }}$ Sigma-Aldrich) and positioned in the sediment with a motorized micromanipulator ( $0.1 \mu \mathrm{m}$ resolution, MU-1; PyroScience) controlled by the microprofiling software Profix (PyroScience). The sensors entered the sediment at $90^{\circ}$ or with an angle between $45^{\circ}$ and $70^{\circ}$ to position the sensor tip at the desired sediment depth and distance from the siphon. This position was not changed until the end of the measurement, where the microoptodes were gradually moved forward until touching the siphon, in order to independently determine the distance between the recording position and the siphon. dying macrofauna were removed, and the defaunated cores were re-equipped with stirring bars (60 RPM) and kept open in the aerated aquarium. After $2 \mathrm{wk}$, when the OPD returned to stable values of $2.8 \pm 0.4 \mathrm{~mm}$, all cores were incubated on 6 different occasions to monitor the total $\mathrm{O}_{2}$ uptake (TOU) (see Section 2.4.2). The TOU remained at a stable value of $25.5 \pm 4.6 \mathrm{mmol} \mathrm{O}_{2} \mathrm{~m}^{-2} \mathrm{~d}^{-1}$, and conditions were considered restored from the anoxic manipulation. At this point (i.e. $29 \mathrm{~d}$ after the anoxic period), 1 soft-shell clam was added to each of the large cores, which corresponded to an animal density of 141 ind. $\mathrm{m}^{-2}$, a population size naturally occurring in many coastal habitats (Mermillod-Blondin et al. 2003, Forster \& Zettler 2004). The acclimated animals buried themselves, and incubation experiments commenced $1 \mathrm{wk}$ after their addition. Four of these animals had each a microoptode fixed in proximity of the pedal gape (' $\mathrm{P}$ ' in Fig. 1 b) to continuously monitor the $\mathrm{O}_{2}$ availability at this position. During the incubations, the siphon activity of all clams was regularly monitored by visual observations. The small cores served as defaunated controls. Here, all benthic fluxes (see Section 2.4.2) remained constant throughout the experimental time, thus confirming quasi steadystate conditions after the initial exposure to anoxia and re-oxygenation. 


\subsubsection{Benthic fluxes measurements}

The TOU and benthic nutrients exchange $\left(\mathrm{NH}_{4}{ }^{+}\right.$, $\mathrm{NO}_{2}{ }^{-}$and $\mathrm{NO}_{3}$ ) were measured by parallel incubation of cores on consecutive days for $3 \mathrm{wk}_{\text {; }}$ subsequently, the denitrification rate was determined with a final destructive incubation. The $\mathrm{O}_{2}$ concentration in the enclosed water volume was monitored with 2point calibrated contactless sensor spots fixed on the inner wall of the lids (OXSP5, PyroScience). During each incubation, the $\mathrm{O}_{2}$ was measured in discrete intervals until values had decreased from the initial $100 \%$ to $70-75 \%$ air-saturation. This generally took between 0.8 and $4.1 \mathrm{~h}$ depending on the animal activity patterns. TOU rates were calculated from the linear changes of the $\mathrm{O}_{2}$ concentration over time accounting for the enclosed water volume and sediment area.

Benthic nutrient fluxes were measured separately in $12 \mathrm{~h}$ long incubations, during which the water level in the aquarium was temporarily lowered below the upper core rims. Sediment cores were capped but continuously aerated with needles connected to an air pump and inserted in one of the sampling ports in the lid covering each core (Fig. 1b). The gentle aeration (>6 $\mathrm{cm}$ above the sediment surface) had no apparent impact on the clam behaviour and allowed us to maintain fully oxic conditions during these incubations. Samples $(5 \mathrm{ml})$ of enclosed water were collected 1 to 4 times per hour, depending on the clam activity. Samples were filtered through $0.2 \mu \mathrm{m}$ pore-size cellulose acetate and immediately frozen $\left(-20^{\circ} \mathrm{C}\right)$ until analysed spectrophotometrically on a continuous flow analyser (Skalar San ${ }^{\text {Plus }}$ ). The $\mathrm{NH}_{4}{ }^{+}$ concentration (precision: $\pm 0.1 \mu \mathrm{mol} \mathrm{l}^{-1}$ ) was determined with a modified Berthelot reaction (Krom 1980); oxidised nitrogen $\left(\mathrm{NO}_{\mathrm{X}}: \mathrm{NO}_{2}{ }^{-}+\mathrm{NO}_{3}{ }^{-}\right)$and $\mathrm{NO}_{2}{ }^{-}$were measured following the cadmium and sulphanilamide reduction methods, respectively (Grasshoff et al. 1999). The $\mathrm{NO}_{3}{ }^{-}$concentration (precision: $\pm 0.5 \mu \mathrm{mol} \mathrm{l}^{-1}$ ) was calculated as the difference between $\mathrm{NO}_{\mathrm{X}}$ and $\mathrm{NO}_{2}{ }^{-}$. The benthic fluxes were calculated from the linear changes in concentrations over time accounting for the gradual reduction of the water volume (see Section 2.5).

\subsubsection{Sediment denitrification measurements}

Denitrification rate was determined in a final incubation with the nitrogen isotope pairing technique adapted from Nielsen (1992). In short, the submerged cores were sealed without entrapping bubbles, and the water was amended with $20 \mu \mathrm{mol} \mathrm{l}^{-1}$ of ${ }^{15} \mathrm{NO}_{3}{ }^{-}$

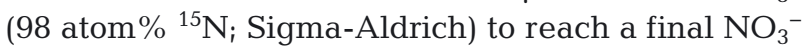
concentration of $\sim 60 \mu \mathrm{mol} \mathrm{l}^{-1}$. During the incubations, the internal $\mathrm{O}_{2}$ concentration was monitored as previously described, and when required, the $\mathrm{O}_{2}$ level was restored to near air-saturation by replacing $8 \%$ of the water volume with $\mathrm{O}_{2}$-saturated water amended with ${ }^{15} \mathrm{NO}_{3}{ }^{-}$. This procedure allowed to incubate sediment cores for $6 \mathrm{~h}$ while avoiding oxic conditions below $70 \%$ air-saturation but preserving the initial $\mathrm{NO}_{3}{ }^{-}$isotopic ratio. Isotopic determination of dinitrogen $\left(\mathrm{N}_{2}\right)$ gas from the replaced water (see below for storage and analyses) enabled to correct the denitrification rates for the amount of $\mathrm{N}_{2}$ sampled. At the end of the incubation, denitrification activity was terminated by adding $50 \% \mathrm{ZnCl}_{2}$ solution (12 $\mu \mathrm{l}$ per $\mathrm{cm}^{3}$ of slurred sediment), and the sediment was gently slurred using a glass rod. The defaunated control cores were slurred to $4 \mathrm{~cm}$ sediment depth, while large cores were slurred to the bottom $(\sim 20 \mathrm{~cm})$ to include labelled $\mathrm{N}_{2}$ that had accumulated around the buried animal. Duplicate samples for ${ }^{29} \mathrm{~N}_{2}$ and ${ }^{30} \mathrm{~N}_{2}$ were taken from each core by a glass syringe and transferred to $12.4 \mathrm{ml}$ exetainers spiked with $50 \mu \mathrm{l} \mathrm{ZnCl}_{2}$ (50\%). Within $2 \mathrm{wk}$, dissolved $\mathrm{N}_{2}$ was extracted in a He headspace and analysed on a Delta $\mathrm{V}$ isotope ratio mass spectrometer. Denitrification rates were calculated from the random pairing of ${ }^{15} \mathrm{~N}$ and ${ }^{14} \mathrm{~N}$ in $\mathrm{N}_{2}$ assuming uniform mixing of labelled and non-labelled $\mathrm{NO}_{3}{ }^{-}$in the sediment (Nielsen 1992). Anaerobic $\mathrm{NH}_{4}{ }^{+}$oxidation (anammox) rates have previously been shown to be negligible at the collection site (data not shown). The approach is thoroughly reviewed by Robertson et al. (2019).

\subsection{Replication and data analysis}

The $\mathrm{O}_{2}$ availability at the shell-sediment interface in ' $\mathrm{P}$ ' (Fig. 1) was monitored in 4 specimens sitting in the cores with central stirring and 3 specimens sitting in the mini-flume for a total time over $3000 \mathrm{~h}$ (Table 1). All animals buried themselves from the initial flat orientation at the sediment surface; thus, the initial $24 \mathrm{~h}$ were influenced by the burrowing activity of the animal and were not included in the analysis. In general, analysis of $\mathrm{O}_{2}$ data at the shell-sediment interface focused on the duration of the oxic-anoxic periods and timing of their occurrence. The miniflume set-up also enabled to relate the benthic $\mathrm{O}_{2}$ dynamics with the siphon aperture area obtained from the concurrent time-lapse pictures $(\sim 1000 \mathrm{~h})$. The ac- 
celerometer data were used to calculate the body orientation of the soft-shell clam as roll angle = $\tan ^{-1}\left[x /\left(y^{2}+z^{2}\right)\right]$, where the $x, y$ and $z$ are the sway, surge and heave measured by the data loggers, respectively (Robson \& Mansfield 2014, Coquereau et al. 2016). As clams contract their valves when ejecting water from the pedal gape (authors' pers. obs.), recorded variations in the relative change of the roll angle were used as a proxy for the contraction amplitude of the valve. Overall, 3 main behavioural stages were discerned: resting $(\mathrm{R})$, ventilation $(\mathrm{V})$ and pedal water ejection (PWE). We calculated the relative occurrence of the behavioural stages by normalizing to the measuring period of each investigation and then averaging the results of the respective investigation. The PWE stage corresponded to periods with $\mathrm{O}_{2}$ concentration $>1 \mu \mathrm{mol} \mathrm{l}{ }^{-1}$ at ' $\mathrm{P}$ ' position on the shell, while $\mathrm{R}$ corresponded to periods with siphon retracted into the sediment. The $\mathrm{V}$ stage was identified as periods with siphon open at the sediment surface while the shell was embedded in anoxic porewater.

In total, 76 TOU and 40 nutrient flux determinations were conducted on each of the 8 large cores, in parallel with 37 TOU and 22 nutrient incubations on the 4 small control cores (Table 1). The $\mathrm{NO}_{2}{ }^{-}$fluxes contributed to $<6 \%$ of the $\mathrm{NO}_{\mathrm{x}}$ fluxes and therefore are not presented. The overall TOU and nutrient fluxes for each of the incubations were calculated by

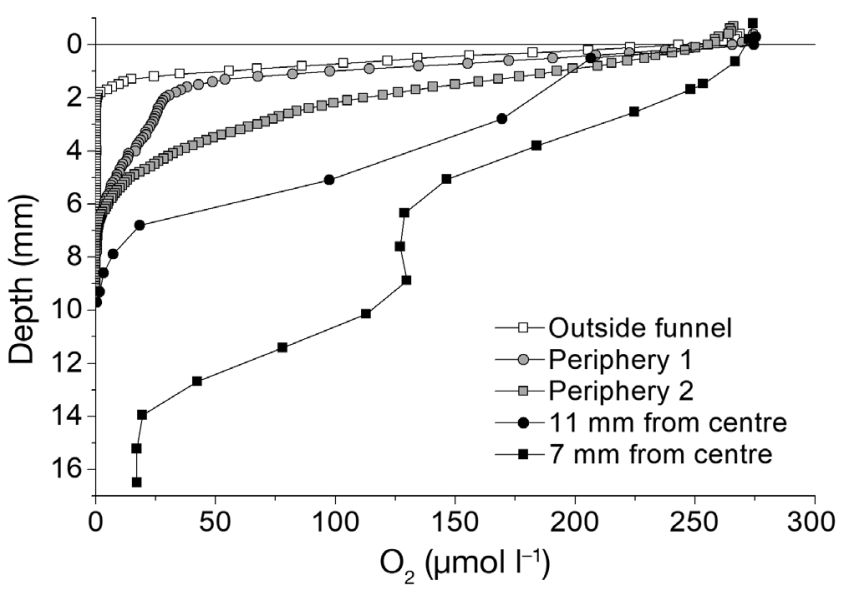

Fig. 2. Examples of vertical sediment $\mathrm{O}_{2}$ profiles measured with microoptode outside (white symbols) and inside the $40 \mathrm{~mm}$ wide funnel above the clams (grey and black symbols). Periphery 1 and 2 were measured vertically just inside the funnel at a position of $20 \mathrm{~mm}$ from the centre. The 2 vertical profiles in the centre of the funnel were resolved by simple geometry from angled profiles that entered the sediment at 11 or $7 \mathrm{~mm}$ from the centre and encompassed a horizontal distance $<5 \mathrm{~mm}$. The OPD increased towards the funnel centre, and values in the centre did not reach anoxia even at $16.5 \mathrm{~mm}$ depth. Zero on the ordinate represents the position of the sediment-water interface linear regression of all concentration data as a function of incubation time, water volume and area. To resolve the effect of each behavioural stage, fluxes were also calculated from 2 consecutive concentration measurements, and the flux during each behavioural stage was derived by averaging all 2-point fluxes obtained for the respective stages. Fluxes for the R and V + PWE stages were obtained for all large cores, while the $\mathrm{V}$ and PWE stages were discerned only in the 4 cores where a microoptode was glued to the clam's shell. One-way ANOVA and post hoc Tukey's test (if $\mathrm{p}<0.05$ ) were run in SigmaPlot (version 12.5) to test the effect of $M$. arenaria on benthic fluxes (control, overall, R, V + PWE, V and PWE) and denitrification rates (control and overall). All data met the assumptions of normal distribution (ShapiroWilk's test) and homogeneity of variance (Levene's test). All results are presented as mean \pm SD.

\section{RESULTS}

\subsection{Microscale $\mathrm{O}_{2}$ dynamics around buried Mya arenaria}

The investigated specimens buried to a sediment depth of 15 to $20 \mathrm{~cm}$ (distance from sediment surface to lower shell edge), and they markedly affected the benthic $\mathrm{O}_{2}$ availability. The animals induced $\mathrm{O}_{2}$ dynamics that were highly dependent upon the animal activity, and 3 distinct behavioural stages were observed: resting $(\mathrm{R})$, ventilation $(\mathrm{V})$ and pedal water ejection (PWE). In general, the clam activity alternated between $\mathrm{R}$ stages and periods with a visible siphon at the sediment surface ( $V$ and PWE stages). The occurrence of V + PWE stages did not follow any distinct pattern, but their durations were typically proportional to that of the previous R period (i.e. long $R$ stages were followed by long V + PWE stages).

During the R stage, the animals retracted the siphon into the sediment, leaving a funnel-shaped depression at the surface, on average $1 \mathrm{~cm}$ deep and with a diameter of 3 to $4 \mathrm{~cm}$. All the 14 vertical $\mathrm{O}_{2}$ profiles measured either outside the funnel area, in undisturbed or defaunated sediment cores, revealed a similar OPD at the sediment surface (i.e. primary interface) of $2.3 \pm 0.6 \mathrm{~mm}$. However, the OPD tripled at the funnel periphery, and it further increased to $>16 \mathrm{~mm}$ towards the centre during R (Fig. 2), presumably due to passive pressure-driven advection induced by the water flow above the sediment.

The R stage lasted from 0.7 to $24 \mathrm{~h}$, during which the entire animal was embedded in anoxic sediment 
$\left(\mathrm{O}_{2}<1 \mu \mathrm{mol} \mathrm{l}^{-1}\right)$. The $\mathrm{R}$ stage was interrupted by the extension and opening of the siphon a few $\mathrm{mm}$ above the sediment surface, in the centre of the funnel. The siphon elongation modified the funnel structure, but the sediment reworking was generally confined to the central area of the funnel, and the sediment depression remained during all the activity stages.

The siphon remained visible and open for $>40 \%$ of the total time of investigation, during either the $\mathrm{V}$ or PWE behavioural stage. The V stage occurred for $28 \pm 18 \%$ of the investigated time and lasted from 0.5 to $7 \mathrm{~h}$. The V stage started when the siphon opened above the sediment surface, and after a lag phase of at least $20 \mathrm{~min}$, this induced a gradual oxygenation of the sediment surrounding the siphon at the investigated depths (Fig. 3). Subsequently, the $\mathrm{O}_{2}$ distribution typically reached a quasi-steady state within 10 min and now extended $\sim 4 \mathrm{~mm}$ from the siphon into the surrounding sediment. This corresponded to a horizontal OPD from the cylindrical siphon (i.e. radial OPD at the secondary interface) that was $70 \%$ higher than the $2.3 \mathrm{~mm}$ OPD at the primary interface. Overall, there was a temporal correlation between the aperture area of the siphon (i.e. the sum of the inhalant and exhalant canals area) and the $\mathrm{O}_{2}$ avail-

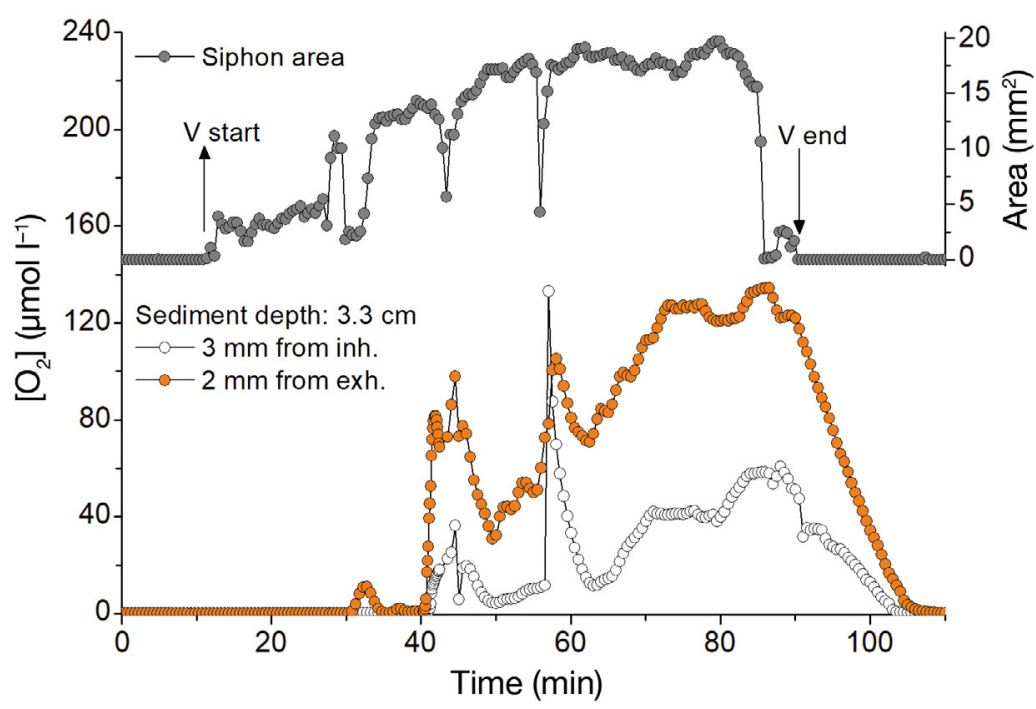

Fig. 3. Typical $\mathrm{O}_{2}$ distribution in the sediment surrounding the siphon of Mya arenaria during a ventilation stage (V) lasting $79 \mathrm{~min}$. The V stage commenced when the siphon elongated and opened above the sediment surface (upward arrow, shift from resting [R] to V) and ended when the siphon completely retracted below the sediment surface (downward arrow, shift from $\mathrm{V}$ to $\mathrm{R}$ ). The $\mathrm{O}_{2}$ concentration at the sediment depth of $3.3 \mathrm{~cm}$ was recorded at $30 \mathrm{~s}$ intervals with microoptodes positioned at $\sim 3 \mathrm{~mm}$ from the inhalant canal (white symbols) and $\sim 2 \mathrm{~mm}$ from the exhalant canal (orange symbols). The difference in the oxic conditions at the respective positions was attributed to decreasing $\mathrm{O}_{2}$ concentration with distance from the siphon. Overall oxia lasted for $76 \mathrm{~min}$ and were thus similar to the duration of active ventilation through the siphon ability in the sediment surrounding the siphon, and typically sudden drops in the siphon area increased the $\mathrm{O}_{2}$ concentration in the sediment adjacent the therefore induced irregular $\mathrm{O}_{2}$ fluctuations in the sediment surrounding the siphon. When animals shifted from V to R stage, the siphon retraction (area $=0 \mathrm{~mm}^{2}$ at $\sim 90 \mathrm{~min}$ ) was accompanied by a gradual $\mathrm{O}_{2}$ decrease, and anoxia was reached 20 to 30 min later (Fig. 3). The V stage thus induced oxia in the sediment volume surrounding the siphon, while the shell-mounted microoptodes revealed that the actual shell-sediment interface remained anoxic (data not shown).

When the siphon was open at the sediment surface, the V stage alternated with the PWE stage, during which a dynamic oxic halo encompassed the entire clam. The transition from V to PWE was marked by an abrupt contraction of the valves and siphon closure, as well as by an initial increase in $\mathrm{O}_{2}$ concentration on the shell-sediment interface (Fig. 4). While the valve contractions resolved by the accelerometers were unique for the PWE stage, variations in siphon area during the PWE and V stages were similar. During PWE, the oxic conditions rapidly changed at the shell-sediment interface, but $\mathrm{O}_{2}$ was typically recorded first at the pedal gape (' $\mathrm{P}$ ') and then at positions further up the ventral margin ('M1' and 'M2' in Fig. 5). Similarly, the $\mathrm{O}_{2}$ concentration at ' $\mathrm{P}$ ' position reached a maximum $\sim 20 \mathrm{~s}$ after the behavioural shift, whereas this took $\sim 30 \mathrm{~s}$ at 'M1' and 'M2' (Fig. 5), reflecting that oxia transplanted upwards from the pedal gape position. Subsequently, the $\mathrm{O}_{2}$ concentration at ' $\mathrm{P}$ ' gradually decreased, and $\mathrm{O}_{2}$ depleted after $5 \pm 2$ min unless followed by another water ejection cycle (Figs. 4 \& 5).

A single PWE stage was often the result of multiple water ejection cycles that occurred in short succession overlapping into a longer period that lasted between 1 and $5 \mathrm{~h}$. Analysis of the oxic-anoxic oscillations at the shell-sediment interface showed that the PWE stage occurred with a frequency of $2.1 \pm 0.9 \mathrm{~h}^{-1}$ and overall induced oxia at ' $\mathrm{P}$ ' position on the shellsediment interface for $15 \pm 6 \%$ of the total time of investigation. The extent of the $\mathrm{O}_{2}$ fluctuations within each cycle suggests that the initial advection induced by the animal activity was followed by a diffusive 

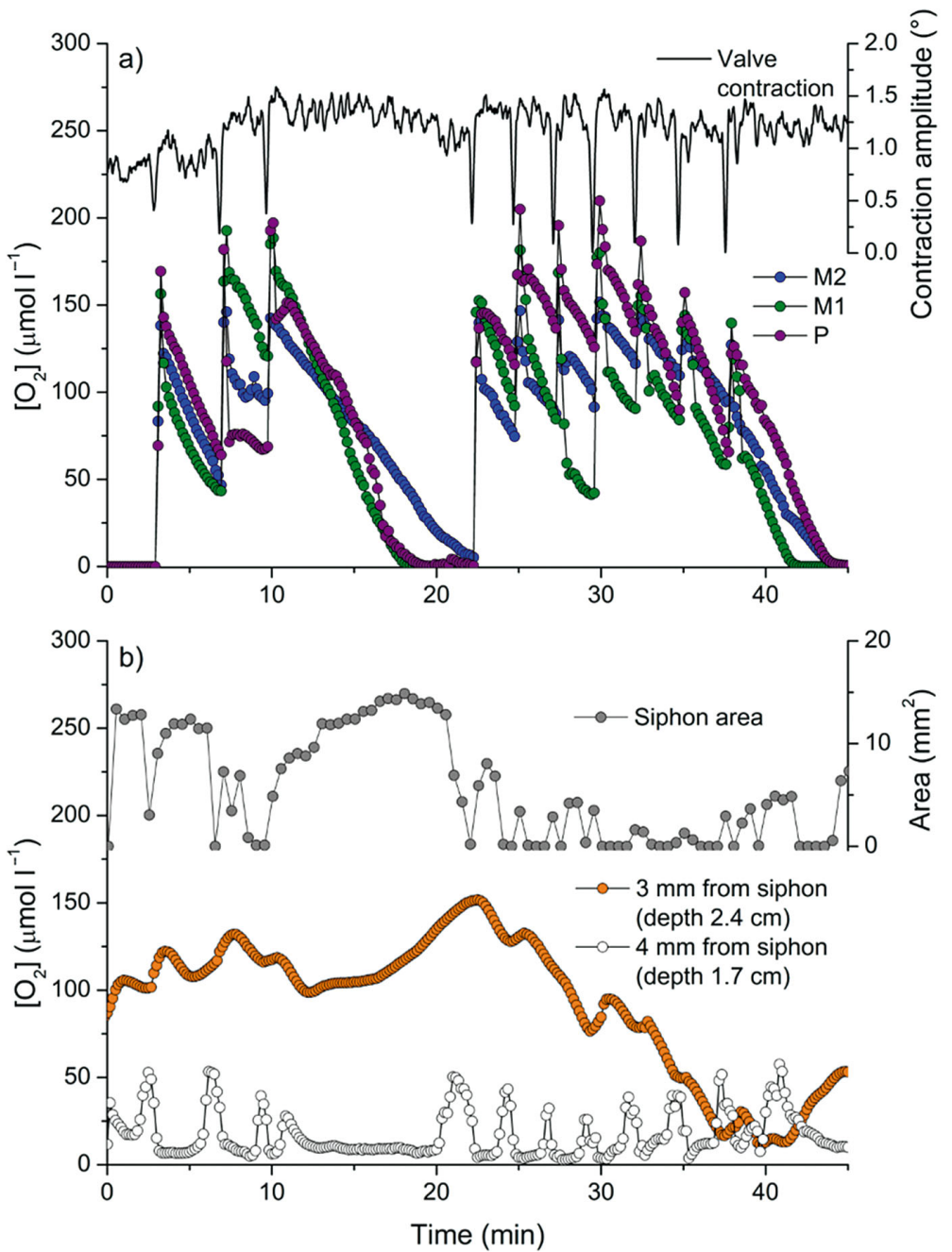

Fig. 4. Typical $\mathrm{O}_{2}$ fluctuations in the sediment surrounding Mya arenaria during a period of intense pedal water ejection (PWE) activity. (a) Each water ejection cycle commenced with a drop in the contraction amplitude to $0^{\circ}$ or near $0^{\circ}$, as recorded by the accelerometer loggers. This induced the rapid oxygenation of the deepest ' $\mathrm{P}$ ' position and subsequently at the upper 'M1' and 'M2' positions on the shell, indicating that oxia embedded the entire length of shell. The drop in contraction amplitude coincides with (b) closure of the siphon, presumably to pressurize the water inside the mantle cavity. The PWE led to asynchronous $\mathrm{O}_{2}$ fluctuations in the upper sediment surrounding the siphon above the right (orange symbols) and left valve (white symbols). The selected example reflects 2 consecutive $\mathrm{PWE}_{;} \mathrm{O}_{2}$ data were recorded at $10 \mathrm{~s}$ intervals

transport and consumption of $\mathrm{O}_{2}$ in the surrounding sediment. The upward-moving $\mathrm{O}_{2}$ spikes initiated at the pedal gape were often synchronised with $\mathrm{O}_{2}$ fluctuations in the upper sediment surrounding the siphon. For example, the $\mathrm{O}_{2}$ pulses recorded on the shell transplanted up to the region above the right valve (orange symbols in Fig. 4) but differed from those recorded above the left valve (white symbols in Fig. 4), suggesting asymmetric porewater advection around the clam. Therefore, the PWE stage induced pulsing oxic conditions around the ventral margin of the shell and the overlying regions adjacent to the siphon due to farreaching advective porewater transport. Despite the asynchronous fluctuations, the sediment adjacent to the siphon exhibited stable oxic conditions during $\mathrm{PWE}_{\text {; }}$ thus, oxia here amounted to $43 \pm 17 \%$ of the total time of investigation (Fig. 6).

\subsection{Benthic $\mathrm{O}_{2}$ exchange in sediment inhabited by Mya arenaria}

The TOU rates were measured between 7 and 11 times in each large core inhabited by $M$. arenaria and in each of the small control cores. The presence of clams increased the overall TOU 3-fold compared to the control cores $\left(F_{5,35}=19.05, \mathrm{p}<0.001\right.$; Table 2). However, the dynamic benthic $\mathrm{O}_{2}$ distribution induced by the behavioural patterns translated into variable TOU during the respective incubations (Fig. 7).

During the $\mathrm{R}$ stage, the TOU remained constant with a value of $30.8 \pm 7.7 \mathrm{mmol} \mathrm{O}_{2}$ $\mathrm{m}^{-2} \mathrm{~d}^{-1}$, which is not different from the TOU measured in the defaunated cores $(p>0.05$; Table 2), indicating that the passive water advection in the funnel area did not affect the average TOU significantly. However, the TOU was greatly enhanced by the $V$ and PWE stages (Fig. 7), and periods of combined V and PWE behaviours increased the TOU to an average rate of $125.4 \pm 27.1 \mathrm{mmol}$ $\mathrm{O}_{2} \mathrm{~m}^{-2} \mathrm{~d}^{-1}$. The TOU rates during the $\mathrm{V}$ and PWE stages were highly variable, but appeared to be similar ( $p>0.05$; Table 2). A complete $\mathrm{V}$ stage typically exhibited relatively high rates immediately after the transition from the R stage. For instance, at the onset of the $\mathrm{V}$ activity, the TOU could reach peak values $>200 \mathrm{mmol} \mathrm{O}_{2} \mathrm{~m}^{-2} \mathrm{~d}^{-1}$ (Fig. 7), or 2-fold higher than the general TOU rates resolved during the V stage: $108.3 \pm 32.5 \mathrm{mmol} \mathrm{O}_{2} \mathrm{~m}^{-2} \mathrm{~d}^{-1}$. In the reverse transition (i.e. siphon retraction into the sediment), the TOU gradually decreased to values typical of the R stage (data not shown). In contrast, the PWE stage irregularly interrupted the $\mathrm{V}$ stage and elevated the average TOU to $125.3 \pm 44.3 \mathrm{mmol} \mathrm{O}_{2} \mathrm{~m}^{-2}$ $\mathrm{d}^{-1}$, but values fluctuated extensively during these periods from 53.6 to $178.6 \mathrm{mmol} \mathrm{O}_{2} \mathrm{~m}^{-2} \mathrm{~d}^{-1}$ without any distinct pattern (Fig. 7). 

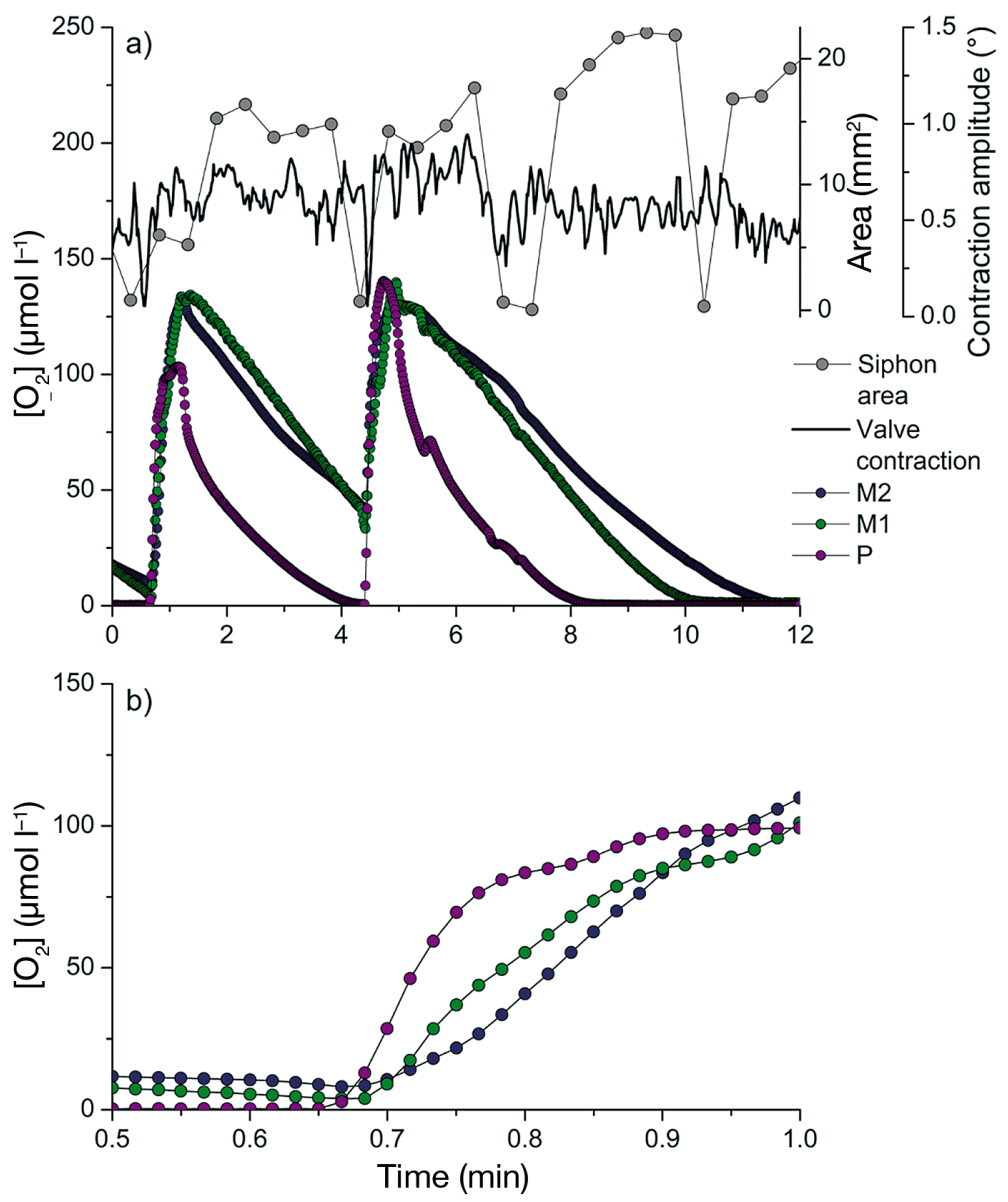

Fig. 5. Example of high-resolution $\mathrm{O}_{2}$ dynamics at the shell-sediment interface induced by the pedal water ejection (PWE). (a) The PWE was associated with a simultaneous closure of the siphon and valve contraction, represented by siphon area and contraction amplitude drop to $\sim 0$. (b) Close-up showing the rapid $\mathrm{O}_{2}$ fluctuations at the shell-sediment interface during a single water ejection cycle, which started at the deepest ' $\mathrm{P}$ ' position and transplanted upwards to 'M1' and 'M2'. The $\mathrm{O}_{2}$ concentration was recorded at $1 \mathrm{~s}$ intervals

The TOU rates quantified in cores with $M$. arenaria were not significantly correlated with the animals' dry weight, shell length or burial depth. Rather, it appeared that the relative duration of the respective behavioural stages was crucial for the overall TOU rate measured for each specimen. Combining the results from the different experimental approaches, we quantified the relative contribution of the different behavioural stages for the overall TOU at the experimental conditions (Fig. 8). The results show that periods of V and PWE had a disproportionately large influence on the overall TOU relative to their occurrence time. This clearly documents the importance of $M$. arenaria activity patterns for the benthic $\mathrm{O}_{2}$ consumption rate and the need for correct representation of faunal behaviour when assessing the TOU in such habitats.

\subsection{Benthic nutrient exchange and denitrification rates in sediment inhabited by M. arenaria}

The benthic nutrient fluxes $\left(\mathrm{NH}_{4}{ }^{+}\right.$and $\mathrm{NO}_{3}{ }^{-}$) were measured between 4 and 6 times in each large core inhabited by $M$. arenaria and in each of the small cores. In general, the presence of clams changed the influxes of $\mathrm{NH}_{4}{ }^{+}$into effluxes $\left(F_{5,35}=21.41, \mathrm{p}<0.001\right.$; Table 2), from $-0.5 \pm 0.1 \mathrm{mmol} \mathrm{m}^{-2} \mathrm{~d}^{-1}$ to $3.0 \pm$ $1.0 \mathrm{mmol} \mathrm{m}^{-2} \mathrm{~d}^{-1}$. In contrast, the overall $\mathrm{NO}_{3}{ }^{-}$influx induced by the clams $(-1.2 \pm$ $0.8 \mathrm{mmol} \mathrm{m}^{-2} \mathrm{~d}^{-1}$ ) remained similar to the rate measured in the defaunated cores of $-1.1 \pm 0.4 \mathrm{mmol} \mathrm{m}^{-2} \mathrm{~d}^{-1}\left(F_{5,35}=1.54, \mathrm{p}=0.21\right)$.

Similar to what was observed for the TOU, the $\mathrm{NH}_{4}{ }^{+}$fluxes during the $\mathrm{R}$ stage remained similar to that of the control cores $(p>0.05$; Table 2), while $\mathrm{NH}_{4}{ }^{+}$fluxes were greatly enhanced during the V and PWE stages $(\mathrm{p}<$ 0.001; Table 2). The onset of the $\mathrm{V}$ and the PWE stages induced high release of $\mathrm{NH}_{4}{ }^{+}$ from the sediment (Fig. 9), presumably related to the outflushing of $\mathrm{NH}_{4}{ }^{+}$accumulated in the sediment surrounding the clam or potentially stored in the mantel cavity. This high initial flux gradually declined to an average efflux of $6.3 \pm 1.4 \mathrm{mmol} \mathrm{m}^{-2} \mathrm{~d}^{-1}$ during the $\mathrm{V}$ and PWE stages. Occasionally, we even observed an influx of $\mathrm{NH}_{4}{ }^{+}$following an initial burst of $\mathrm{NH}_{4}{ }^{+}$outflux due to an elevated level in the overlying water, for example during R and V stages following PWE (Fig. 9).

The presence of the clams induced highly variable $\mathrm{NO}_{3}{ }^{-}$fluxes without enhancing the long-term net exchange of $\mathrm{NO}_{3}{ }^{-}$(Table 2). The $\mathrm{NO}_{3}{ }^{-}$ fluxes measured during the respective behavioural stages varied greatly, probably due to the frequent behavioural shifts and complex irrigation patterns. However, there was a tendency for lower $\mathrm{NO}_{3}{ }^{-}$ uptake during $\mathrm{R}$ compared to periods of $\mathrm{V}$ and PWE. In particular, the intense sediment irrigation during prolonged PWE often induced extensive $\mathrm{NO}_{3}{ }^{-}$ uptake up to $-6.7 \mathrm{mmol} \mathrm{m}^{-2} \mathrm{~d}^{-1}$ (Fig. 9). The PWE stage thus modulated the direct transport of both $\mathrm{O}_{2}$ and $\mathrm{NO}_{3}{ }^{-}$from the overlying water down to 15 to $20 \mathrm{~cm}$ sediment depth, concurrent with outflushing of the interstitial $\mathrm{NH}_{4}{ }^{+}$. The behavioural patterns of $M$. arenaria therefore had a strong impact on the benthic availability of $\mathrm{O}_{2}, \mathrm{NH}_{4}{ }^{+}$and $\mathrm{NO}_{3}{ }^{-}$, which is expected to affect the denitrification activity in the irrigated sediment. 


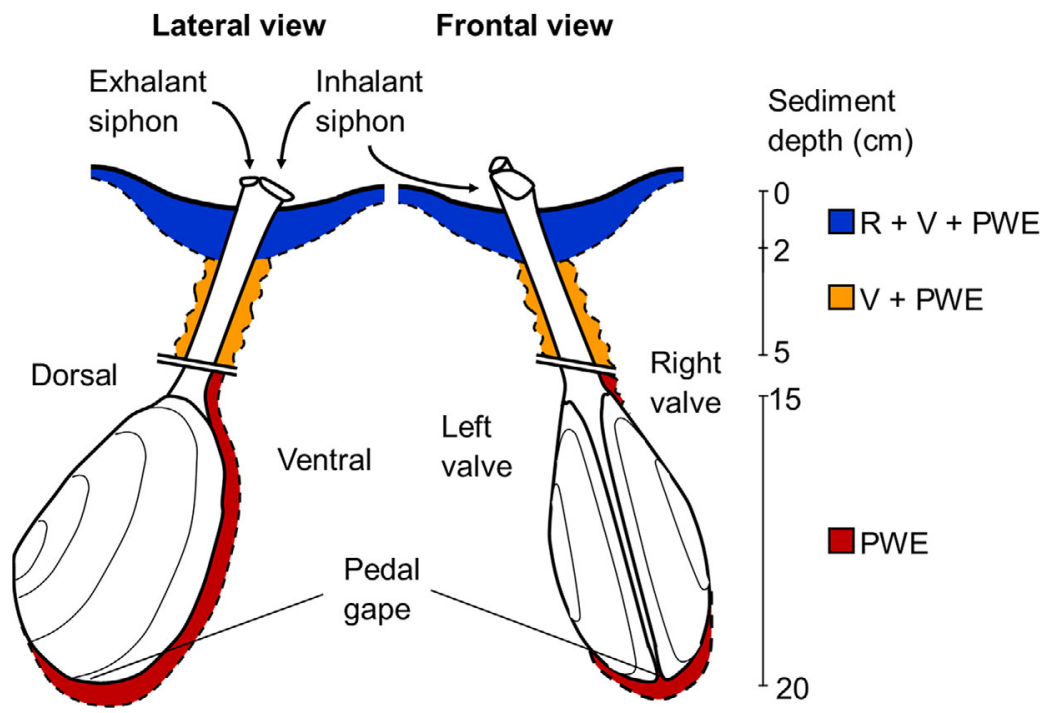

Fig. 6. Schematic of Mya arenaria lateral and frontal views and overview of the sediment oxygenation induced by the different behavioural stage. The $\mathrm{O}_{2}$ penetration depth (OPD) increased in the funnel area (blue) during all 3 stages, exceeding $1.6 \mathrm{~cm}$ depth in the centre during the resting $(\mathrm{R})$ stage. After the siphon elongation above the sediment surface, indicating the end of the $\mathrm{R}$ stage, the oxic zone expanded to at least $5 \mathrm{~cm}$ depth and extended $4 \mathrm{~mm}$ into the sediment surrounding the siphon. This occurred for $43 \%$ of the time (yellow) that encompassed both the ventilation (V) and pedal water ejection (PWE) stages. The PWE stage further extended oxia to the shell-sediment interface on the ventral margin (e.g. between 15 and $20 \mathrm{~cm}$ depth) for $15 \%$ of the time (red)

Table 2. Total $\mathrm{O}_{2}$ uptake (TOU), benthic nutrients $\left(\mathrm{NH}_{4}{ }^{+}\right.$and $\left.\mathrm{NO}_{3}{ }^{-}\right)$exchange and denitrification rates (na: not applicable) for cores inhabited with $M$. arenaria (141 ind. $\mathrm{m}^{-2}$ ) and defaunated control cores. In addition to the overall rates, benthic fluxes measured for the respective behavioural stages of $M$. arenaria are also reported: resting (R), ventilation (V) and pedal water ejection (PWE). Values are reported as mean $\pm \mathrm{SD}$; number of cores (n) reported in each row. Asterisks denote values significantly different from the control $\left(1\right.$-way ANOVA; $\left.{ }^{*} \mathrm{p}<0.05,{ }^{* *} \mathrm{p}<0.01,{ }^{* * *} \mathrm{p}<0.001\right)$

\begin{tabular}{|lccccc|}
\hline & $\mathrm{n}$ & $\begin{array}{c}\mathrm{TOU} \\
\left(\mathrm{mmol} \mathrm{O}_{2} \mathrm{~m}^{-2} \mathrm{~d}^{-1}\right)\end{array}$ & $\mathrm{NH}_{4}{ }^{+}$ & $\begin{array}{c}\mathrm{NO}_{3}{ }^{-} \\
\left(\mathrm{mmol} \mathrm{N} \mathrm{m}^{-2} \mathrm{~d}^{-1}\right)\end{array}$ & Denitrification \\
\hline Overall & 8 & $80.5 \pm 23.9^{*}$ & $3.0 \pm 1.0^{*}$ & $-1.2 \pm 0.8$ & $0.7 \pm 0.1^{* * *}$ \\
$\mathrm{R}$ & 8 & $30.8 \pm 7.7$ & $0.4 \pm 1.3$ & $-0.9 \pm 0.9$ & na \\
$\mathrm{V}+\mathrm{PWE}$ & 8 & $125.4 \pm 27.1^{* * *}$ & $6.3 \pm 1.4^{* * *}$ & $-1.7 \pm 0.6$ & na \\
$\mathrm{V}$ & 4 & $108.3 \pm 32.5^{* * *}$ & $4.6 \pm 2.1^{* *}$ & $-1.7 \pm 1.1$ & na \\
$\mathrm{PWE}$ & 4 & $125.3 \pm 44.3^{* * *}$ & $7.5 \pm 3.2^{* * *}$ & $-2.0 \pm 1.3$ & na \\
Control & 4 & $24.5 \pm 6.1$ & $-0.5 \pm 0.1$ & $-1.1 \pm 0.4$ & $0.3 \pm 0.1$ \\
$F$ (df) & & $19.05(5,35)$ & $21.41(5,35)$ & $1.54(5,35)$ & $47.66(1,11)$ \\
$\mathrm{p}$ & & $<0.001$ & $<0.001$ & 0.21 & $<0.001$ \\
\hline
\end{tabular}

bined $\mathrm{V}$ and PWE stages of variable duration, while 1 never elongated the siphon above the sediment surface. However, the denitrification rates were not directly correlated to the relative occurrence of the $\mathrm{V}$ and PWE stages during the $6 \mathrm{~h}$ incubations, suggesting a temporal decoupling between the resolved irrigation patterns and the elevated benthic denitrification activity.

\section{DISCUSSION}

It is well established that infauna activity modulates benthic solute exchange and diagenetic processes in marine sediments, but the importance of their behavioural patterns on biogeochemical processes has only recently been appreciated. In general, shifts in benthic fauna behaviour can be related to changes in light (Wenzhöfer \& Glud 2004, Karlson 2007), tidal flow (Aller \& Yingst 1978), ambient $\mathrm{O}_{2}$ concentration (Dales et al. 1970, Kristensen 1983), predation pressure (Smee \& Weissburg 2006) and availability of suspended food (Riisgård et al. 2003, Glud et al. 2016). In some species, the optimal timing of activity patterns is tuned by biological clocks, and behavioural shifts exhibit distinct circadian or circatidal cycles (Palmer 2000, Rosenberg \& Lundberg 2004, Last et al. 2009). These shifts affect the environmental conditions of bioturbated sediments and thus the microbial performance and biogeochemical function of surface sediments. To understand how infauna affects sediment biogeochemistry, it is necessary to evaluate the unique bioirrigation patterns on appropriate

In the control cores, the denitrification rate amounted to $0.3 \pm 0.1 \mathrm{mmol} \mathrm{N} \mathrm{m}^{-2} \mathrm{~d}^{-1}$, a value that increased to $0.7 \pm 0.1 \mathrm{mmol} \mathrm{N} \mathrm{m} \mathrm{N}^{-1}$ in cores containing clams $\left(F_{1,11}=47.66, \mathrm{p}<0.001\right.$; Table 2$)$. During the isotope pairing technique incubations, 7 of the investigated specimens exhibited periods of com- spatial and temporal scales (Volkenborn et al. 2012). The present study has revealed 3 distinct behavioural stages of the ubiquitous soft-shell clam Mya arenaria and resolved how these affect the benthic $\mathrm{O}_{2}$ and nitrogen dynamics in coastal sediments. 

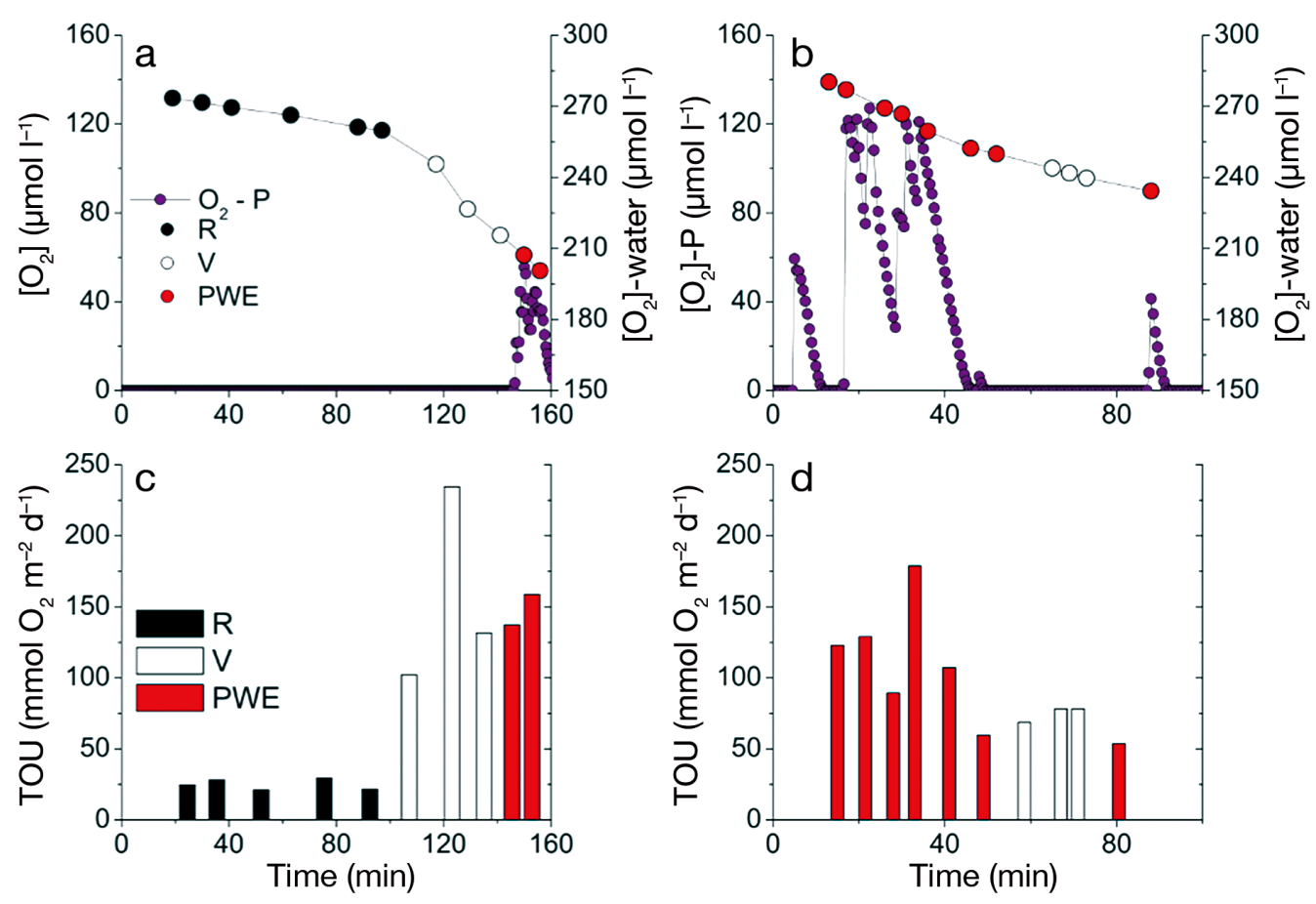

Fig. 7. $(\mathrm{a}, \mathrm{b})$ Examples of $\mathrm{O}_{2}$ reduction in the enclosed water of intact core incubations and (c,d) the corresponding total $\mathrm{O}_{2}$ uptake (TOU). The different colours indicate the independently determined behavioural stage of the clam: resting (R) ventilation (V) and pedal water ejection (PWE). (a,b) The oxic conditions at the shell-sediment interface (purple circles) were recorded every $30 \mathrm{~s}$ with a microoptode glued at ' $\mathrm{P}$ ' position on the shell (see Fig. 1). The derived TOU rates clearly reflect the behavioural stage displayed by the clams

\subsection{Irrigation patterns of $M$. arenaria and implications for sediment oxygenation}

Advection driven by boundary flow and sediment topography grossly enhance solute transport in permeable and semipermeable sediments (Huettel et al. 2003). Advective porewater transport is, however, also markedly enhanced by the presence of infauna, partly due to bioirrigation and partly due to modification of the sediment topography by formation of mounds and funnels (Huettel \& Gust 1992, Volkenborn et al. 2007). This was also exemplified by the present study, where $M$. arenaria created a permanent oxygenated funnel that extended the OPD in the sediment overlying the clam. Extrapolating our point measurements to the entire $4 \mathrm{~cm}$ wide funnel revealed that the oxic sediment volume in the funnel was 5 -fold larger than in the neighbouring unaffected areas. Likely, the periodic siphon movements increased the local sediment permeability, which facilitated deeper oxygen penetration above the shell even when the animal was in the resting stage.
In addition to maintaining the funnel, the mechanical movements of the siphon during $\mathrm{V}$ activity induced a dynamic oxic halo that embedded the siphon to at least $5 \mathrm{~cm}$ depth. As a result, this sediment region was oxidized and differed from the surrounding reduced and constantly anoxic sediment. In situ observations directly confirmed that the oxi-

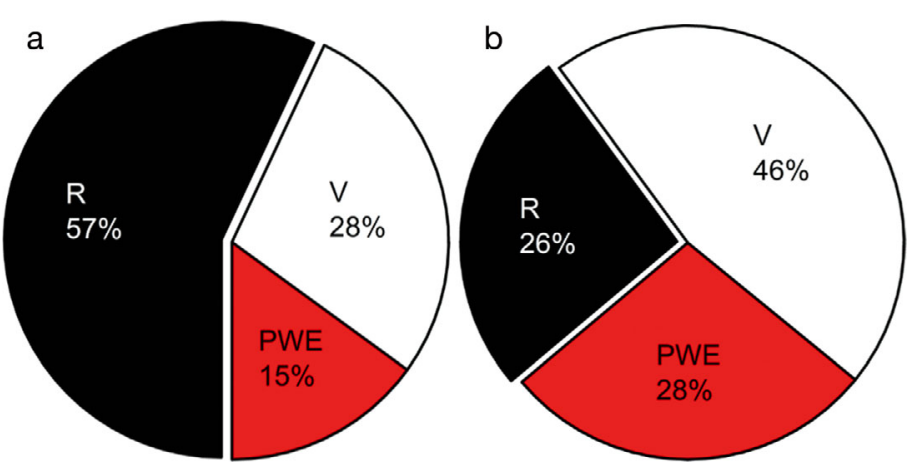

Fig. 8. Influence of the relative duration of the 3 behavioural stages of Mya arenaria on the overall total benthic $\mathrm{O}_{2}$ uptake (TOU). (a) Relative time of occurrence for resting (R), ventilation (V) and pedal water ejection (PWE) as resolved in the mini-flume set-up. (b) Respective contribution of each behavioural stage to the overall TOU measured during sediment incubations at an animal density of 141 ind. $\mathrm{m}^{-2}$ 

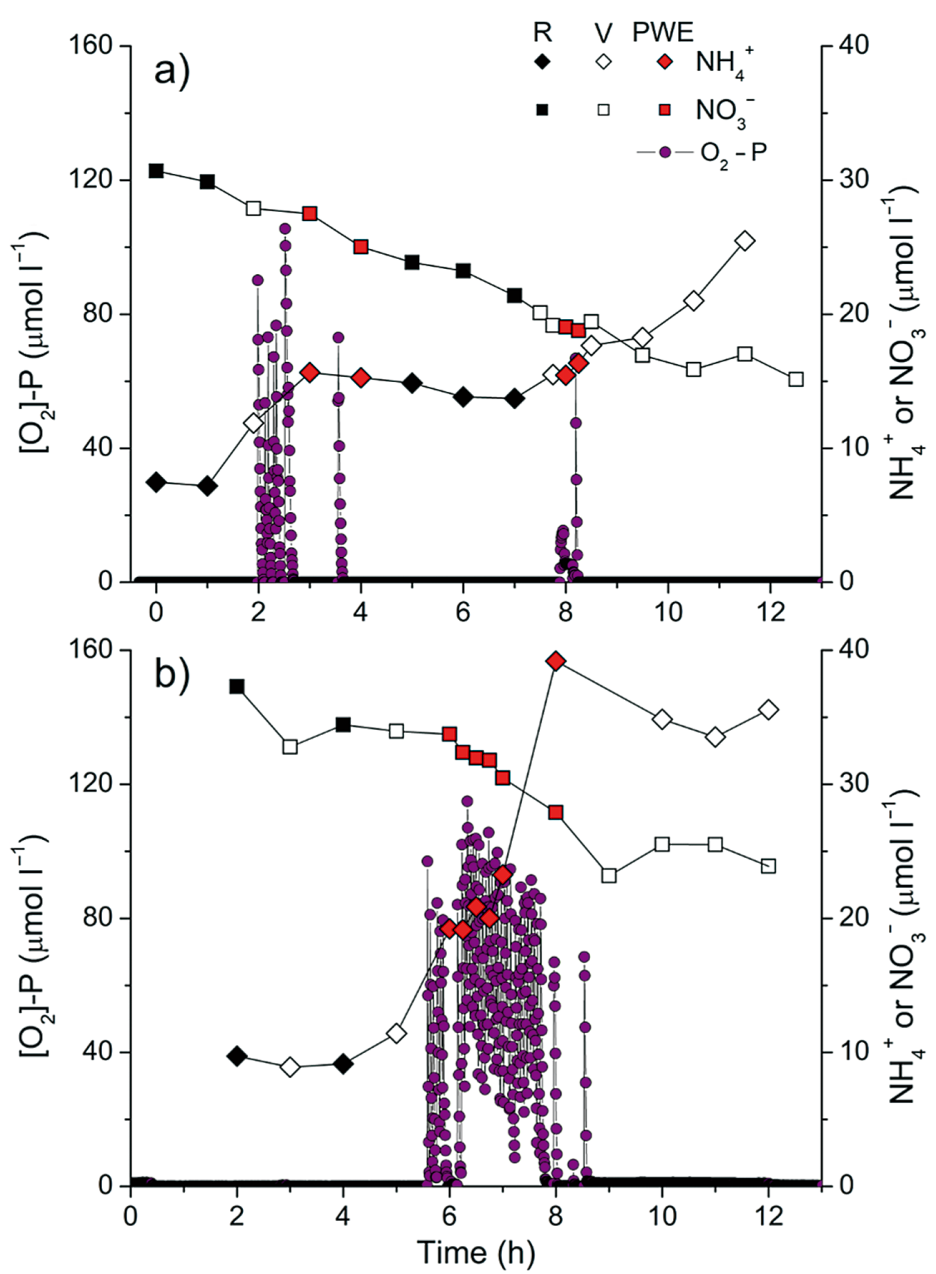

Fig. 9. Typical $\mathrm{NH}_{4}{ }^{+}$(diamonds) and $\mathrm{NO}_{3}{ }^{-}$(squares) dynamics in the enclosed water during two $(\mathrm{a}, \mathrm{b}) 12 \mathrm{~h}$ sediment incubations maintained under fully air-saturated conditions. The different colours indicate the independently determined behavioural stage displayed by $M$. arenaria: resting (R), ventilation (V) and pedal water ejection (PWE). The $\mathrm{O}_{2}$ concentration (purple circles) was recorded every $30 \mathrm{~s}$ at ' $\mathrm{P}$ ' position on the shell (see Fig. 1). Both examples show enhanced solute exchange during the $V$ and PWE stages compared to the R stage

dized sediment layer encompassed the entire siphon length, implying the oxygenation of a sediment volume of 35 to $45 \mathrm{~cm}^{3}$ for the animals studied here. It is possible that such sediment oxygenation is driven by $\mathrm{O}_{2}$ diffusion through the ventilating siphon (Pelegrí \& Blackburn 1995); however, the gas exchange across the siphon of active bivalves has to our knowledge not been independently quantified. We estimated the diffusion-driven radial OPD around a stationary siphon applying the volume-specific $\mathrm{O}_{2}$ consumption rate of the sediment and the procedure outlined by Fenchel (1996). Assuming a molecular transport coefficient through the siphon tissue similar to that in water, we derived a maximum radial OPD value of $2.1 \mathrm{~mm}$ at a sediment depth of $5 \mathrm{~cm}$, which is roughly half the values actually observed. Additionally, the most prominent behavioural stage displayed by the clams was $\mathrm{R}$, when the siphon was retracted; thus, it is unlikely that $\mathrm{O}_{2}$ diffusion though the siphon alone could oxidize the sediment surrounding the siphon. It follows that advective processes must have contributed to the sediment oxygenation and oxidation around the siphon. During the V stage, advection of the oxic overlying water into the sediment could be induced by the movements of the siphon. The gradual percolation of the overlying water would thus explain the lag phase observed between the onset of the $\mathrm{V}$ stage and oxygenation of the siphon surroundings at 3 to $5 \mathrm{~cm}$ depth. Furthermore, the PWE stage induced extensive porewater advection around the entire clam, but with a general upward expansion of the plume.

Disturbed $M$. arenaria can bury by a hydraulic mechanism that relies on the ejection of water through the pedal gape while using the foot to grip the substrate (Checa \& Cadée 1997). This mechanism is accomplished by increased pressurization inside the mantle cavity following closure of the siphon and contraction of the valves (Checa \& Cadée 1997). Although the brief closure of the siphon represents the main behavioural component of in situ clams (Thorin et al. 1998), to date it has not been documented that buried individuals would eject water through the pedal gape. In previous studies, the bioirrigation of deeper sediment in proximity to the shell has therefore been overlooked and occasional local oxidation attributed to the leaking of water and passive diffusional $\mathrm{O}_{2}$ loss from the valve gape (Forster \& Zettler 2004). However, even when pumping fully oxic water into the siphon, the $\mathrm{O}_{2}$ concentration in the mantle cavity water of $M$. arenaria is maintained below $7 \mathrm{~mol} \mathrm{l}^{-1}$ (Abele et al. 2010), and during the V stage, the shell is constantly embedded in anoxia. In this study, we documented for the first time that PWE induces oxygenation and oxidation of the sediment encompassing the entire ventral shell margin and that this activity represents an important behavioural component even for buried stationary adult $M$. arenaria. The display of PWE could benefit the animal by lowering sediment compaction, thereby easing valve and siphon movements. This could also facilitate vertical movements in the sediment, which $M$. arenaria can exhibit in response to hypoxic events (Rosenberg et al. 1991, 
Taylor \& Eggleston 2000) and predation (Flynn \& Smee 2010). Furthermore, the oxygenation induced by PWE can alleviate exposure to reduced toxic compounds, such as $\mathrm{H}_{2} \mathrm{~S}$ and $\mathrm{NH}_{4}{ }^{+}$. M. arenaria has a low tolerance to $\mathrm{H}_{2} \mathrm{~S}$ intrusion (Le Pennec et al. 1995), and the periodic oxygenation promoted by the PWE can increase the chemical and microbial oxidation similarly to that observed for other burrowing species (Wang \& Chapman 1999, Behrens et al. 2007). Indeed, Hansen et al. (1996) documented lower $\mathrm{H}_{2} \mathrm{~S}$ and $\mathrm{Fe}^{2+}$ concentrations in the oxidized sediment adjacent to $M$. arenaria. The transport of $\mathrm{O}_{2}$ into otherwise anoxic sediments can oxidize free $\mathrm{H}_{2} \mathrm{~S}$ and regenerate reactive iron oxides, which increases the benthic $\mathrm{H}_{2} \mathrm{~S}$ buffer capacity and promotes the adsorption of $\mathrm{HPO}_{4}{ }^{2-}$ by iron oxides (Anschutz et al. 1998, Waldbusser et al. 2004). The PWE activity could thus modulate important ecosystem functions by increasing the resilience against inherent $\mathrm{H}_{2} \mathrm{~S}$ production and reducing internal phosphorus loading. The unrecognized PWE behaviour could have implications for previous conceptual bioirrigation assessments, in which $M$. arenaria were considered to have little sediment irrigation activity (Wrede et al. 2018).

The presence of adult specimens of $M$. arenaria at a density of 141 ind. $\mathrm{m}^{-2}$ resulted in an overall TOU rate of $80.5 \pm 23.9 \mathrm{mmol} \mathrm{O}_{2} \mathrm{~m}^{-2} \mathrm{~d}^{-1}$, which was 3-fold higher than the value of the control cores. This confirms that $M$. arenaria can significantly increase the benthic community $\mathrm{O}_{2}$ demand (Emerson et al. 1988, Schade et al. 2019). The differentiation of the 3 behavioural stages revealed that TOU was enhanced by the occurrence of V and PWE stages. M. arenaria can respond to sudden changes in light by contracting the photosensitive siphon (Light 1930). In the mini-flume investigation where a clam was exposed to a $12 \mathrm{~h}$ light:12 h dark cycle, the displayed activity patterns did not follow a diel cycle, and the relative occurrence of the different stages was similar to those of the animals kept in the dark (data not shown). Diel cycles in benthic fauna activity patterns can represent an adaptation against visual predators (Rosenberg \& Lundberg 2004, Wenzhöfer \& Glud 2004), but this was apparently not the case for $M$. arenaria collected at our study site. Clam ventilation activity could be regulated by food availability (Riisgård et al. 2003), and the relative occurrence of $\mathrm{V}$ could thus be higher during phytoplankton blooms in spring. Similarly, it can be speculated that PWE would be stimulated during summer, due to enhanced production and accumulation of $\mathrm{H}_{2} \mathrm{~S}$ in the porewater (Al-Raei et al. 2009). Such changes in the relative occurrence of $\mathrm{V}$ and PWE would thus have consequences for irrigation activity and the benthic community $\mathrm{O}_{2}$ demand, underpinning the importance of discerning the effect of faunal activity patterns. The difference in TOU between cores with $M$. arenaria and defaunated cores is ascribed to the combined $\mathrm{O}_{2}$ consumption in the sediment and respiration of the clam itself. Using the allometric relation found by Schade et al. (2019), we derived the respiration rate for naturally behaving $M$. arenaria of the present study. At the experimental temperature and density, the calculated respiration rate of $M$. arenaria amounted to $10.6 \pm 1.3 \mathrm{mmol} \mathrm{O}_{2} \mathrm{~m}^{-2} \mathrm{~d}^{-1}$, corresponding to $14 \pm 5 \%$ of the overall TOU measured in this study. It follows that the $\mathrm{O}_{2}$ uptake in the irrigated sediment amounted to $45.4 \pm 23.7 \mathrm{mmol} \mathrm{O}_{2} \mathrm{~m}^{-2} \mathrm{~d}^{-1}$ (i.e. clam overall TOU minus clam respiration and TOU in control) and exceeded the uptake rate of the control cores by a factor of 1.9, confirming that the sediment adjacent to the clams represents a hotspot for oxidation processes and microbial respiration with potential implications for benthic nitrogen cycling.

\subsection{M. arenaria influence on benthic nitrogen cycling}

Bioirrigation can release reduced solutes accumulated in the sediment, such as $\mathrm{NH}_{4}{ }^{+}$, and replenish the porewater with oxidants, such as $\mathrm{NO}_{3}{ }^{-}$(e.g. Aller 1994). Similar patterns were resolved by our flux determinations obtained for the different behavioural stages of $M$. arenaria. However, the behavioural shifts must have induced a highly complex distribution of nutrients in the irrigated sediment, which translated into variable rates for $\mathrm{NH}_{4}{ }^{+}$efflux and $\mathrm{NO}_{3}{ }^{-}$influx. The release of $\mathrm{NH}_{4}{ }^{+}$ was clearly regulated by the extent of sediment irrigation during each behavioural stage, which implies highly dynamic $\mathrm{NH}_{4}{ }^{+}$concentrations in the sediment around the clam. During $\mathrm{R}_{1} \mathrm{NH}_{4}{ }^{+}$released by remineralization can accumulate in the sediment surrounding the clam; thus, effluxes are small. In contrast, the high $\mathrm{NH}_{4}{ }^{+}$effluxes of the $\mathrm{V}$ and PWE stages reflected outflush of $\mathrm{NH}_{4}{ }^{+}$from the irrigated sediment. Particularly, the deeper and upwardmoving sediment irrigation of PWE induced the greatest release of $\mathrm{NH}_{4}{ }^{+}$. Although we did not directly examine the clam contribution to the $\mathrm{NH}_{4}{ }^{+}$ efflux, the excretion rate for adult $M$. arenaria

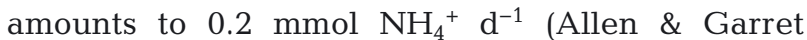
$1971)$ and was thus considered to have minor influence on the V (and PWE) fluxes. 
Concurrently, the $\mathrm{V}$ and PWE stages exhibited a tendency to increase the benthic $\mathrm{NO}_{3}{ }^{-}$uptake, but fluxes for each behavioural stage were highly variable, and overall, the presence of clams did not significantly affect the net exchange of $\mathrm{NO}_{3}{ }^{-}$. The intermittent sediment irrigation of the clam during the incubations has, however, presumably induced highly dynamic distributions of $\mathrm{O}_{2}$ and $\mathrm{NO}_{3}{ }^{-}$, but the direct implications of the behavioural shifts on nitrification, denitrification and their coupling are difficult to resolve. The experimental data indicate an overall stimulation of denitrification in the irrigated sediment, which is supported by in situ $\mathrm{NO}_{3}{ }^{-}$uptake values suggesting that $M$. arenaria increase sediment denitrification (Thoms et al. 2018). Periodic redox oscillations can enhance denitrification rates (Gilbert et al. 2016), which is most likely mediated by facultative aerobic bacteria that exhibit a lag when shifting from aerobic respiration to denitrification (Smith \& Tiedje 1979). However, sediment oxygenation also stimulates nitrification, and elevated potential nitrification has been measured in the sediment surrounding $M$. arenaria, particularly in the proximity of the siphon (Henriksen et al. 1983). Therefore, the intermittent sediment irrigation during PWE and V can sustain nitrification while temporarily inhibiting denitrification until the $\mathrm{O}_{2}$ has been consumed. Following a lag period, denitrification will then be expected to increase, thus giving a complex temporal relation between the transport-reaction processes and the exchange and distribution of $\mathrm{NO}_{3}{ }^{-}$in the porewater.

Overall, the denitrification rate corresponded to $63 \%$ of the measured $\mathrm{NO}_{3}{ }^{-}$uptake in sediments with clams. The denitrification rate attributed to clam presence amounted to $0.4 \pm 0.1 \mathrm{mmol} \mathrm{N} \mathrm{m}^{-2} \mathrm{~d}^{-1}$. This rate is 3 -fold higher than that measured for younger, smaller individuals of $M$. arenaria at 8-fold higher densities (Pelegrí \& Blackburn 1995). It cannot be excluded this difference was related to the different experimental conditions such as the longer preincubation time used in this study (i.e. period between animal addition to the cores and beginning of the incubations). However, it is possible that adult specimens of $M$. arenaria, by living in deeper sediment, irrigate larger sediment volumes and thus have a larger impact on benthic nitrogen cycling than younger specimens. This idea is supported by the lower net $\mathrm{NH}_{4}{ }^{+}$effluxes induced by young specimens (<40 mm shell length; 764 ind. $\mathrm{m}^{-2}$ ) of $<0.1 \mathrm{mmol}$ $\mathrm{m}^{-2} \mathrm{~d}^{-1}$ (Michaud et al. 2006) compared to that of $4.0 \pm 1.4 \mathrm{mmol} \mathrm{m}^{-2} \mathrm{~d}^{-1}$ observed for the adult clams of this study (56-75 $\mathrm{mm}$ shell length; 141 ind. $\mathrm{m}^{-2}$ ). Therefore, given the behavioural patterns of adult $M$. arenaria, the size distribution rather than the density may regulate the extent to which coastal sediments act as a sink for bioavailable nitrogen.

\section{CONCLUSIONS}

Traditionally, benthic processes and fluxes in bioirrigated sediments have been derived from chamber or core incubations, with little emphasis on the behavioural component or consideration on how enclosure might affect animal behaviour. However, an increasing number of studies are independently assessing the implications of variable fauna behaviour for solute dynamics. Some of the most successful techniques employed to quantitatively and qualitatively describe the behavioural implications include inert tracers such as bromide and fluorescent dyes (Mermillod-Blondin et al. 2004, Timmermann et al. 2006, Jovanovic et al. 2014), pressure transducers and planar optodes (Zhu et al. 2006, Volkenborn et al. 2012, Glud et al. 2016). However, direct biogeochemical implications of behavioural patterns and responses remain scarce. In the present study, we identified 3 behavioural stages of Mya arenaria $(\mathrm{R}, \mathrm{V}$ and PWE) using $\mathrm{O}_{2}$ optode arrays, accelerometers and siphon imaging. The link between behavioural stages and benthic solute exchange was resolved by parallel incubation approaches. The behavioural shifts changed benthic distribution and exchange of $\mathrm{O}_{2}, \mathrm{NH}_{4}{ }^{+}$and $\mathrm{NO}_{3}{ }^{-}$, with the PWE stage inducing bursts in benthic fluxes and much deeper sediment irrigation and oxidation. Although it occurred for $15 \%$ of the total time of investigation, the PWE clearly had important implication for the benthic transport and reaction processes. This highlights the importance of behavioural patterns of infauna for the biogeochemical function of marine sediments, such as nutrient regeneration and sediment redox dynamics, and the need for applying innovative approaches to resolve the environmental importance of infauna with complex behavioural patterns.

Acknowledgements. We thank Anni Glud for assistance and the construction of microoptodes, Laurent Chauvaud for providing accelerometers and technical advice on their application and Lorenzo Rovelli for assistance with handling of accelerometer data. Stefan Forster and Mikael Sejr are thanked for valuable discussion of the results. Three anonymous reviewers are thanked for contributing to improve the manuscript. The study was financially supported by the European Union's Horizon 2020 research and innovation programme (Grant agreement No. 669947; HADES-ERC) and the Danish National Research Council (FNU; 060202276B) awarded to R.N.G. 


\section{LITERATURE CITED}

Abele D, Kruppe M, Philipp EER, Brey T (2010) Mantle cavity water oxygen partial pressure $\left(\mathrm{Po}_{2}\right)$ in marine molluscs aligns with lifestyle. Can J Fish Aquat Sci 67: 977-986

Al-Raei AM, Bosselmann K, Böttcher ME, Hespenheide B, Tauber F (2009) Seasonal dynamics of microbial sulfate reduction in temperate intertidal surface sediments: controls by temperature and organic matter. Ocean Dyn 59: 351-370

Allen JA, Garret MR (1971) The excretion of ammonia and urea by Mya arenaria L. (Mollusca: Bivalvia). Comp Biochem Physiol A 39:633-642

Aller RC (1982) The effects of macrobenthos on chemical properties of marine sediment and overlying water. In: McCall PL, Tevesz MJS (eds) Animal-sediment relations, Topics in geobiology, Vol 100. Springer, Boston, MA, p 53-102

Aller RC (1994) Bioturbation and remineralization of sedimentary organic matter: effects of redox oscillation. Chem Geol 114:331-345

Aller RC (2014) Sedimentary diagenesis, depositional environments, and benthic fluxes. In: Holland $\mathrm{H}$, Turekian KK (eds) Treatise on geochemistry, 2nd edn. Elsevier, Oxford, p 293-334

Aller RC, Yingst JY (1978) Biogeochemistry of tubedwellings: a study of the sedentary polychaete Amphirite ornata (Leidy). J Mar Res 36:202-254

Aller RC, Yingst JY (1998) The effect of biogenic irrigation intensity and solute exchange on diagenetic reaction rates in marine sediments. J Mar Res 56:905-936

Andersen FØ, Kristensen E (1988) The influence of macrofauna on estuarine benthic community metabolism: a microcosm study. Mar Biol 99:591-603

Anschutz P, Zhong S, Sundby B, Mucci A, Gobeil C (1998) Burial efficiency of phosphorus and the geochemistry of iron in continental margin sediments. Limnol Oceanogr 43:53-64

Behrens JW, Stahl HJ, Steffensen JF, Glud RN (2007) Oxygen dynamics around buried lesser sandeels Ammodytes tobianus (Linnaeus 1785): mode of ventilation and oxygen requirements. J Exp Biol 210:1006-1014

Bertics VJ, Ziebis W (2009) Biodiversity of benthic microbial communities in bioturbated coastal sediments is controlled by geochemical microniches. ISME J 3:1269-1285

* Bertics VJ, Ziebis W (2010) Bioturbation and the role of microniches for sulfate reduction in coastal marine sediments. Environ Microbiol 12:3022-3034

* Boudreau BP, Marinelli RL (1994) A modelling study of discontinuous biological irrigation. J Mar Res 52:947-968

*Brey T (1991) The relative significance of biological and physical disturbance: an example from intertidal and subtidal sandy bottom communities. Estuar Coast Shelf Sci 33:339-360

* Checa AG, Cadée GC (1997) Hydraulic burrowing in the bivalve Mya arenaria Linnaeus (Myoidea) and associated ligamental adaptation. J Moll Stud 63:157-171

Coquereau L, Jolivet A, Hegaret H, Chauvaud L (2016) Short-term behavioural responses of the great scallop Pecten maximus exposed to the toxic alga Alexandrium minutum measured by accelerometry and passive acoustics. PLOS ONE 11:e0160935

Dales RP, Magnum CP, Tichy JC (1970) Effects of changes in oxygen and carbon dioxide concentrations on ventilation rhythms in onuphid polychaetes. J Mar Biol Assoc UK 50: 365-380

Emerson CW, Minchinton TE, Grant J (1988) Population structure, biomass, and respiration of Mya arenaria L. on temperate sandflat. J Exp Mar Biol Ecol 115:99-111

Engel M, Behnke A, Klier J, Buschbaum C, Volkenborn N, Stoeck T (2012) Effects of the bioturbating lugworm Arenicola marina on the structure of benthic protistan communities. Mar Ecol Prog Ser 471:87-99

* Fenchel T (1996) Worm burrows and oxic microniches in marine sediments. I. Spatial and temporal scales. Mar Biol 127:289-295

Flynn AM, Smee DL (2010) Behavioral plasticity of the softshell clam, Mya arenaria (L.), in the presence of predators increases survival in the field. J Exp Mar Biol Ecol 383:32-38

*Forster S, Graf G (1995) Impact of irrigation on oxygen flux into the sediment: intermittent pumping by Callianassa subterranea and 'piston-pumping' by Lanice conchilega. Mar Biol 123:335-346

Forster S, Zettler ML (2004) The capacity of the filter-feeding bivalve Mya arenaria L. to affect water transport in sandy beds. Mar Biol 144:1183-1189

Gilbert F, Hulth S, Grossi V, Aller RC (2016) Redox oscillations and benthic nitrogen mineralization within burrowed sediments: an experimental simulation at low frequency. J Exp Mar Biol Ecol 482:75-84

* Glud RN, Gundersen JK, Røy H, Jørgensen BB (2003) Seasonal dynamics of benthic $\mathrm{O}_{2}$ uptake in a semienclosed bay: importance of diffusion and faunal activity. Limnol Oceanogr 48:1265-1276

* Glud RN, Berg P, Stahl H, Hume A, Larsen M, Eyre BD, Cook PLM (2016) Benthic carbon mineralization and nutrient turnover in a Scottish sea loch: an integrative in situ study. Aquat Geochem 22:443-467

Grasshoff K, Kremling K, Ehrnhardt M (1999) Methods of seawater analysis, 3rd edn. Wiley-VCH, Weinheim

*Hansen K, King GM, Kristensen E (1996) Impact of the softshell clam Mya arenaria on sulfate reduction in an intertidal sediment. Aquat Microb Ecol 10:181-194

Heilskov A, Holmer M (2001) Effects of benthic fauna on organic matter mineralization in fish-farm sediments: importance of size and abundance. ICES J Mar Sci 58: 427-434

Henriksen K, Rasmussen MB, Jensen A (1983) Effect of bioturbation on microbial nitrogen transformations in the sediment and fluxes of ammonium and nitrate to the overlaying water. Ecol Bull 35:193-205

Huettel M, Gust G (1992) Impact of bioroughness on interfacial solute exchange in permeable sediments. Mar Ecol Prog Ser 89:253-267

Huettel M, Røy H, Precht E, Ehrenhauss S (2003) Hydrodynamical impact on biogeochemical processes in aquatic sediments. Hydrobiologia 494:231-236

* Jovanovic Z, Larsen M, Organo Quintana C, Kristensen E, Glud RN (2014) Oxygen dynamics and porewater transport in sediments inhabited by the invasive polychaete Marenzelleria viridis. Mar Ecol Prog Ser 504:181-192

Karlson K (2007) Diurnal bioturbating activities of Monoporeia affinis: effects on benthic oxygen and nutrient fluxes. Mar Ecol Prog Ser 331:195-205

Klute A, Dirksen C (1986) Hydraulic conductivity and diffusivity: laboratory methods. In: Klute A (ed) Methods of soil analysis: Part 1-Physical and mineralogical methods. American Society of Agronomy, Madison, WI, p 687-734 
Kristensen E (1983) Ventilation and oxygen uptake by three species of Nereis (Annelida: Polychaeta). I. Effects of hypoxia. Mar Ecol Prog Ser 12:289-297

Kristensen E (2000) Organic matter diagenesis at the oxic/anoxic interface in coastal marine sediments, with emphasis on the role of burrowing animals. Hydrobiologia 426:1-24

Kristensen E, Blackburn TH (1987) The fate of organic carbon and nitrogen in experimental marine sediment systems: influence of bioturbation and anoxia. J Mar Res 45:231-257

Kristensen E, Kostka JE (2005) Macrofaunal burrows and irrigation in marine sediment: microbiological and biogeochemical interactions. In: Kristensen E, Haese RR, Kostka JE (eds) Interactions between macro- and microorganisms in marine sediments. American Geophysical Union, Washington, DC, p 125-157

Kristensen E, Penha-Lopes G, Delefosse M, Valdemarsen T, Quintana CO, Banta GT (2012) What is bioturbation? The need for a precise definition for fauna in aquatic sciences. Mar Ecol Prog Ser 446:285-302

Krom MD (1980) Spectrophotometric determination of ammonia: a study of a modified Berthelot reaction using salicylate and dichloroisocyanurate. Analyst (Lond) 105: 305-316

Kube J (1996) Spatial and temporal variations in the population structure of the soft-shell clam Mya arenaria in the Pomeranian Bay (southern Baltic Sea). J Sea Res 35: 335-344

KLast KS, Bailhache T, Kramer C, Kyriacou CP, Rosato E, Olive PJ (2009) Tidal, daily, and lunar-day activity cycles in the marine polychaete Nereis virens. Chronobiol Int 26:167-183

* Le Pennec M, Beninger PG, Herry A (1995) Feeding and digestive adaptations of bivalve molluscs to sulphiderich habitats. Comp Biochem Physiol A 111:183-189

Light VE (1930) Photoreceptors in Mya arenaria, with special reference to their distribution, structure, and function. J Morphol 49:1-43

Mermillod-Blondin F, Marie S, Desrosiers G, Long B, de Montety L, Michaud E, Stora G (2003) Assessment of the spatial variability of intertidal benthic communities by axial tomodensitometry: importance of fine-scale heterogeneity. J Exp Mar Biol Ecol 287:193-208

* Mermillod-Blondin F, Rosenberg R, François-Carcaillet F, Norling K, Mauclaire L (2004) Influence of bioturbation by three benthic infaunal species on microbial communities and biogeochemical processes in marine sediment. Aquat Microb Ecol 36:271-284

Michaud E, Desrosiers G, Mermillod-Blondin F, Sundby B, Stora G (2006) The functional group approach to bioturbation: II. The effects of the Macoma balthica community on fluxes of nutrients and dissolved organic carbon across the sediment-water interface. J Exp Mar Biol Ecol 337:178-189

* Nielsen LP (1992) Denitrification in sediment determined from nitrogen isotope pairing. FEMS Microbiol Ecol 86: 357-362

Palmer JD (2000) The clocks controlling the tide associated rhythms of intertidal animals. BioEssays 22:32-37

* Pelegrí SP, Blackburn TH (1995) Effect of bioturbation by Nereis sp., Mya Arenaria and Cerastoderma sp. on nitrification and denitrification in estuarine sediments. Ophelia 42:289-299

Riisgård HU, Kittner C, Seerup DF (2003) Regulation of opening state and filtration rate in filter-feeding bivalves
(Cardium edule, Mytilus edulis, Mya arenaria) in response to low algal concentration. J Exp Mar Biol Ecol 284:105-127

Robertson EK, Bartoli M, Brüchert V, Dalsgaard T and others (2019) Application of the isotope pairing technique in sediments: use, challenges, and new directions. Limnol Oceanogr Methods 17:112-136

Kobson AA, Mansfield RP (2014) Overinflated behavioural energetics: using dynamic body acceleration to accurately measure behaviour duration and estimate energy expenditure. Aquat Biol 21:121-126

Rosenberg R, Lundberg L (2004) Photoperiodic activity pattern in the brittle star Amphiura filiformis. Mar Biol 145: 651-656

* Rosenberg R, Hellman B, Johansson B (1991) Hypoxic tolerance of marine benthic fauna. Mar Ecol Prog Ser 79: 127-131

Schade H, Arneth N, Powilleit M, Forster S (2019) Sand gapers' breath: respiration of Mya arenaria (L. 1758) and its contribution to total oxygen utilization in sediments. Mar Environ Res 143:101-110

Seitzinger S, Harrison JA, Böhlke JK, Bouwman AF and others (2006) Denitrification across landscapes and waterscapes: a synthesis. Ecol Appl 16:2064-2090

* Smee DL, Weissburg MJ (2006) Clamming up: environmental forces diminish the perceptive ability of bivalve prey. Ecology 87:1587-1598

* Smith MS, Tiedje JM (1979) Phases of denitrification following oxygen depletion in soil. Soil Biol Biochem 11: 261-267

* Strasser M (1998) Mya arenaria - an ancient invader of the North Sea coast. Helgol Meeresunters 52:309-324

Taylor DL, Eggleston DB (2000) Effects of hypoxia on an estuarine predator-prey interaction: foraging behavior and mutual interference in the blue crab Callinectes sapidus and the infaunal clam prey Mya arenaria. Mar Ecol Prog Ser 196:221-237

*Thoms F, Burmeister C, Dippner JW, Gogina M and others (2018) Impact of macrofaunal communities on the coastal filter function in the Bay of Gdansk, Baltic Sea. Front Mar Sci 5:201

* Thorin S, Bourdages H, Vincent B (1998) Study of siphon activity in Mya arenaria (L.) in the intertidal zone by means of an underwater video camera. J Exp Mar Biol Ecol 224:205-224

*Timmermann K, Banta GT, Glud RN (2006) Linking Arenicola marina irrigation behaviour to oxygen transport and dynamics in sandy sediments. J Mar Res 64:915-938

Vedel A, Andersen BB, Riisgard HU (1994) Field investigations of pumping activity of the facultatively filter-feeding polychaete Nereis diversicolor using an improved infrared phototransducer system. Mar Ecol Prog Ser 103: 91-101

Volkenborn N, Polerecky L, Hedtkamp SIC, van Beusekom EE, de Beer D (2007) Bioturbation and bioirrigation extend the open exchange regions in permeable sediments. Limnol Oceanogr 52:1898-1909

*Volkenborn N, Meile C, Polerecky L, Pilditch CA and others (2012) Intermittent bioirrigation and oxygen dynamics in permeable sediments: an experimental and modeling study of three tellinid bivalves. J Mar Res 70:794-823

Waldbusser GG, Marinelli RL, Whitlatch RB, Visscher PT (2004) The effects of infaunal biodiversity on biogeochemistry of coastal marine sediments. Limnol Oceanogr 49:1482-1492 
Wang F, Chapman PM (1999) Biological implications of sulfide in the sediment-a review focusing on sediment toxicity. Environ Toxicol Chem 18:2526-2532

Wenzhöfer F, Glud RN (2004) Small-scale spatial and temporal variability in coastal benthic $\mathrm{O}_{2}$ dynamics: effects of fauna activity. Limnol Oceanogr 49:1471-1481

Wrede A, Beermann J, Dannheim J, Gutow L, Brey T (2018) Organism functional traits and ecosystem supporting services - a novel approach to predict bioirrigation. Ecol Indic 91:737-743

Editorial responsibility: Martin Solan, Southampton, UK
Zhu Q, Aller RC, Fan Y (2006) Two-dimensional pH distributions and dynamics in bioturbated marine sediments. Geochim Cosmochim Acta 70:4933-4949

* Zwarts L (1991) Seasonal variation in body weight of the bivalves Macoma balthica, Scrobicularia plana, Mya arenaria and Cerastoderma edule in the Dutch Wadden Sea. Neth J Sea Res 28:231-245

Z Zwarts L, Wanink J (1989) Siphon size and burying depth in deposit- and suspension-feeding benthic bivalves. Mar Biol 100:227-240

Submitted: November 30, 2018; Accepted: May 24, 2019

Proofs received from author(s): July 11, 2019 